\title{
Etoposide-induced DNA damage affects multiple cellular pathways in addition to DNA damage response
}

\author{
Fengxiang Wei ${ }^{1}$, Peng $\mathrm{Hao}^{2}$, Xiangzhong Zhang ${ }^{3}$, Haiyan Hu${ }^{4}$, Dan Jiang ${ }^{5}$, Aihua \\ Yinn $^{6}$, Lijuan Wen ${ }^{1,7}$, Lihong Zheng ${ }^{8}$, Jeffrey Zheru $\mathrm{He}^{9}$, Wenjuan Mei ${ }^{10,12}$, Hui \\ Zeng $^{11,12}$ and Damu Tang ${ }^{12}$ \\ ${ }^{1}$ The Genetics Laboratory, Shenzhen Longgang District Maternity and Child Healthcare Hospital, Shenzhen, Guangdong, PR \\ China \\ ${ }^{2}$ Division of Nephrology, The First Affiliated Hospital of Jiamusi University, Jiamusi, Heilongjiang, PR China \\ ${ }^{3}$ Department of Hematology, The Third Affiliated Hospital of Sun Yat-Sen University, Guangzhou, Guangdong, PR China \\ ${ }^{4}$ Department of Obstetrics and Gynecology, Shenzhen Maternal and Child Healthcare Hospital, Southern Medical University, \\ Shenzhen, Guangdong, PR China \\ ${ }^{5}$ Shenzhen Hua Da Clinical Laboratory Center Co., Ltd., Shenzhen, Guangdong, PR China \\ ${ }^{6}$ Maternal and Children Metabolic-Genetic Key Laboratory, Guangdong Women and Children Hospital, Guangzhou, PR China \\ ${ }^{7}$ Zunyi Medical University, Zunyi, Guizhou, PR China \\ ${ }^{8}$ Department of Biogenetics, Qiqihar Medical University, Qiqihar, Heilongjiang, PR China \\ ${ }^{9}$ Harvard Medical School and Massachusetts General Hospital, Boston, MA, USA \\ ${ }^{10}$ Department of Nephrology, The First Affiliated Hospital of Nanchang University, Nanchang, Jiangxi, PR China \\ ${ }^{11}$ Department of Thoracic Surgery, Fourth Hospital of Hebei Medical University, Shijiazhuang City, Hebei, PR China \\ ${ }^{12}$ Division of Nephrology, Department of Medicine, McMaster University, Hamilton, ON, Canada \\ Correspondence to: Fengxiang Wei, email: haowei727499@163.com \\ Damu Tang, email: damut@mcmaster.ca
}

Keywords: etoposide; DNA damage response; gene expression; RNA sequencing

Received: October 14, 2017 Accepted: February 10, 2018 Epub: February 16, 2018 Published: May 08, 2018

Copyright: Wei et al. This is an open-access article distributed under the terms of the Creative Commons Attribution License 3.0 (CC BY 3.0), which permits unrestricted use, distribution, and reproduction in any medium, provided the original author and source are credited.

\section{ABSTRACT}

DNA damage response (DDR) coordinates lesion repair and checkpoint activation. DDR is intimately connected with transcription. However, the relationship between DDR and transcription has not been clearly established. We report here RNA-sequencing analyses of MCF7 cells containing double-strand breaks induced by etoposide. While etoposide does not apparently cause global changes in mRNA abundance, it altered some gene expression. At the setting of fold alteration $\geq 2$ and false discovery rate (FDR) $\leq \mathbf{0 . 0 0 1}$, FDR $<0.05$, or $p<0.05$, etoposide upregulated 96,268 , or 860 genes and downregulated 41, 133, or 503 genes in MCF7 cells. Among these differentially expressed genes (DEGs), the processes of biogenesis, metabolism, cell motility, signal transduction, and others were affected; the pathways of Ras GTPase activity, RNA binding, cytokine-mediated signaling, kinase regulatory activity, protein binding, and translation were upregulated, and those pathways related to coated vesicle, calmodulin binding, and microtubule-based movement were downregulated. We further identified RABL6, RFTN2, FAS-AS1, and TCEB3CL as new DDR-affected genes in MCF7 and T47D cells. By metabolic labelling using 4-thiouridine, we observed dynamic alterations in the transcription of these genes in etoposide-treated MCF7 and T47D cells. During 0-2 hour etoposide treatment, RABL6 transcription was robustly increased at 0.5 and 1 hour in MCF7 cells and at 2 hours in T47D cells, while FAS-AS1 transcription was dramatically and steadily elevated in both cell lines. Taken together, we demonstrate dynamic alterations in transcription and that these changes affect multiple cellular processes in etoposide-induced DDR. 


\section{INTRODUCTION}

DNA damage response (DDR) is the mechanism that guards genome integrity and ensures the faithful transmission of the genetic codes to the next generation cells [1]. Lying in the center of DDR are three PI3 kinaserelated kinases (PIKKs), ATM, ATR, and DNA-PK [2]. ATR is typically activated by single strand DNA (ssDNA) lesions, and is required for maintaining genome stability $[3,4]$; both ATM and DNA-PK are activated by double strand DNA breaks (DSBs), and play essential roles in DSB repair $[1,5,6]$. All three PIKKs, particularly ATM and ATR, preserve genome integrity through coordination of checkpoint activation and DNA lesion repair.

While checkpoint activation and DNA lesion repair are the core components of DDR, repair of DNA lesions or maintenance of genome stability is clearly much more pervasive, in which multiple cellular processes are involved [7]. Cell metabolism is intimately connected with DDR [8,9]; intra- and inter-cellular communications are taking place to pass the message of DDR within cells and in their surrounding [10]; and in the same time preparation is under way for cells to re-enter cell cycle upon lesions being repaired. Collectively, the execution of DDR requires a much broader coordination. This concept is in accordance with the knowledge that DNA damage is induced by multiple sources including external genotoxic materials, internal metabolic products, DNA replication, and RNA metabolism.

Differential regulation of mRNA translation and RNA processing is a major feature of DDR. Both UV and ionizing radiation (IR) selectively inhibit and enhance a set of protein translation through excluding and recruiting mRNA species to polysomes [11, 12]. This selection facilitates the translation of proteins involved in DNA repair [12] and also affects multiple cellular processes [11, 13]. Likewise, selective modulation of gene expression was also demonstrated in other aspects of RNA metabolism, including RNA slicing and processing via the involvement of a set of specific RNA processing factors [14, 15], polyadenylation [16, 17], and export [18, 19]. The collective effects of these selective regulations of RNA metabolism are to ensure the expression of genes involved in DNA damage repair while inhibition of others [19].

The above theme remains with respect to gene transcription. While there is evidence suggesting a global transcription inhibition under DNA damage [20, 21], it is well-established that transcription of $\mathrm{p} 53$ targets is upregulated, including $\mathrm{p} 21^{\mathrm{CIP} 1}$ (CDKN1A), BAX, MDM2, and PUMA [22, 23]. Despite this knowledge, our understanding of the alterations in gene expression during DDR remains unclear. There are also reports favoring local rather than global repression of gene transcription in response to DNA damages [24-27]. Additionally, profiling of gene expression in U87 cells treated with IR revealed a correlation coefficient of 0.92 in mRNA abundance between radiated and non-radiated cells, an observation that is not in line with global transcription repression [28]; IR-upregulated genes were detected both in vitro, in vivo (xenograft tumors), and independent of the p53 status [28-30]; and an elevation in IR dose decreased the level of transcription upregulation [30].

Although modulation of gene expression is an important aspect of DDR, this aspect has not been thoroughly investigated. To advance our understanding on this process, we have profiled gene expression of MCF7 cells treated with etoposide (ETOP) using the state-ofthe-art RNA sequencing technology and performed a thorough pathway analysis on differentially expressed genes (DEGs). We report here that ETOP-induced doublestrand breaks (DSBs) affect gene expression in multiple cellular pathways. During this effort, five novel DDRaffected genes were identified and their transcription kinetics in MCF7 and T47D cells treated with ETOP were investigated.

\section{RESULTS}

\section{ETOP-induced DNA damage does not associate with global alterations in RNA abundance}

Recent developments clearly reveal an intimate connection between RNA metabolism and DDR [19, 3133]. Transcription is a major factor regulating transcript abundance, and is associated with DNA damage. To counter transcription-produced DNA damage, a repair program, transcription-coupled repair (TCR), was developed in cells $[34,35]$. Interestingly, DSBs induced by topoisomerase II $\beta$ have been shown to be an essential component in estrogen-initiated transcription [36] and ETOP-induced DSBs enhance AIRE (autoimmune regulator)-mediated transcription [37]. Although transcript abundance in cells containing IR-induced DSBs has been profiled by cDNA microarray [28-30], it remains unclear how gene expression is associated with DDR. This issue is particularly relevant considering the general believe of global repression of transcription by DNA damage [2427]. To further examine this concept, we first determined the kinetics of ETOP-induced DDR in MCF7 cells. ETOP is a well-established topoisomerase inhibitor and induces DSBs $[38,39]$. At 2 hours (h), ETOP clearly induced DSBs evidenced by the appearance of $\gamma \mathrm{H} 2 \mathrm{AX}$ (Figure $1 \mathrm{~A}$ ) and based on comet assay reported in our previous publication [40]. An increase in CHK2 phosphorylation at threonine 68 further confirmed DDR (Figure 1A). We thus performed an RNA sequencing analysis of MCF7 cells treated with vehicle or ETOP for 2 hours. Scatter plot analysis of 12,324 pairs of transcripts using the normalized FPKM (fragments per kilobase of exon per million fragments mapped) demonstrated a high level of similarity between vehicle- and ETOP-treated cells with 
the correlation coefficient being 0.953 (Figure 1B). These observations suggest that global transcription is unlikely suppressed by ETOP-induced DNA damage. Our results confirmed a previous observation that cDNA microarray analysis revealed a correlation coefficient of 0.92 between mock-treated U87 cells and IR-stimulated cells with respect to mRNA abundance [28]. However, this concept does not exclude the possibility that global transcription is repressed under massive DNA damage.

\section{Alterations of multiple pathways in MCF7 cells treated with ETOP}

Although our observations do not support a global repression of transcription in cells containing DSBs (Figure 1B), a small set of genes were up- and downregulated in MCF7 cells treated with ETOP at the setting of $\log 2$ ratio of treatment/control $\geq 1$ ( 2 fold alteration) and FDR $\leq 0.001$ (Figure 1B). These differentially expressed genes (DEGs) include 96 upregulated genes and 41 downregulated genes in ETOP-treated MCF7 cells (Supplementary Table 1, Table 1) and these DEGs may contribute to a broader aspect of DDR than the classical components: checkpoint activation and lesion repair. To examine this possibility, we carried out a gene ontology (GO) enrichment analysis, which showed an enrichment in the three GO ontologies (molecular function, cellular component, and biological process) and multiple terms within individual GO ontology in MCF7 cells treated with ETOP (Figure 2). Evidence suggests that these three GO ontologies are affected in cells undergoing DDR. The

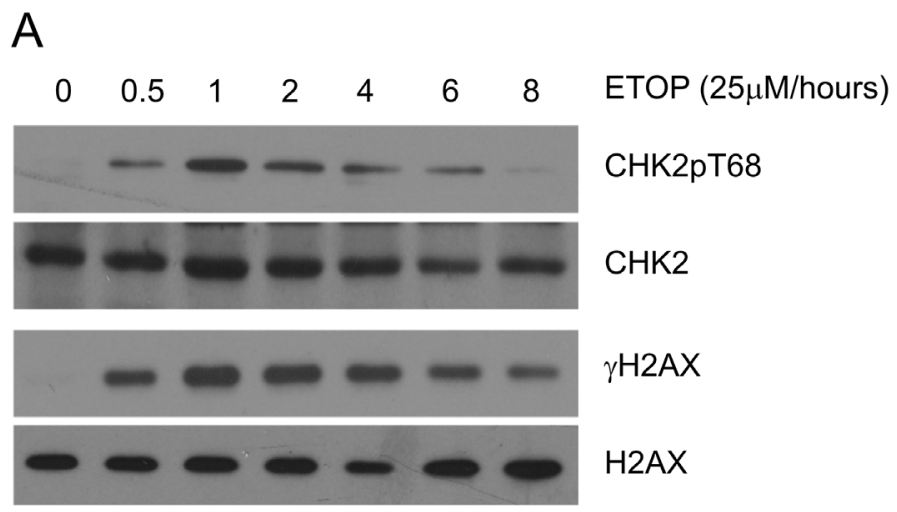

biological processes of GO ontology, including cellular component organization (CCO or biogen), immunological process, and metabolic process [41-44], are regulated by DDR. For the cellular components of GO ontology, "cell" (including cell membrane) [45], "cell part" (cellular components) [46], and "organelle" (including the nucleus, mitochondria, cytoskeleton, and others) [47-49] are contributors to DDR. The molecular function of GO ontology includes 1) protein interactions ("binding") which plays an essential role in the activation of ATM, ATR, and DNAPK $[50,51]$, and 2) "catalytic activity" in which a variety of posttranslational modifications are critical for DDR $[52,53]$. Collectively, the above observations support a broader impact of DDR on multiple cellular functions and systems; their alterations in turn contribute to a variety of aspects of DDR. However, while the above GO analysis provides a general concept for the involvement of broad systems in ETOP-induced DDR, the analysis does not illustrate details on how these systems are engaged.

We thus examined the specific pathways affected by ETOP treatment. For this purpose, we have relaxed the stringency used to identify DEGs from FDR $\leq 0.001$ to FDR $<0.05$ or $p<0.05$ while maintaining $\log 2$ ratio $\geq$ 1. At FDR $<0.05$, the number of the upregulated genes increases to 268 (Supplementary Table 2), and the number of downregulated genes is up to 133 (Supplementary Table $3)$. Further relaxation to $p<0.05$ resulted in increases in upregulated genes and downregulated genes to 860 and 503, respectively (Supplementary Tables 4, 5). The above relax conditions are justified. MCF7 cells express wild type p53, evidenced by p53 stabilization and the

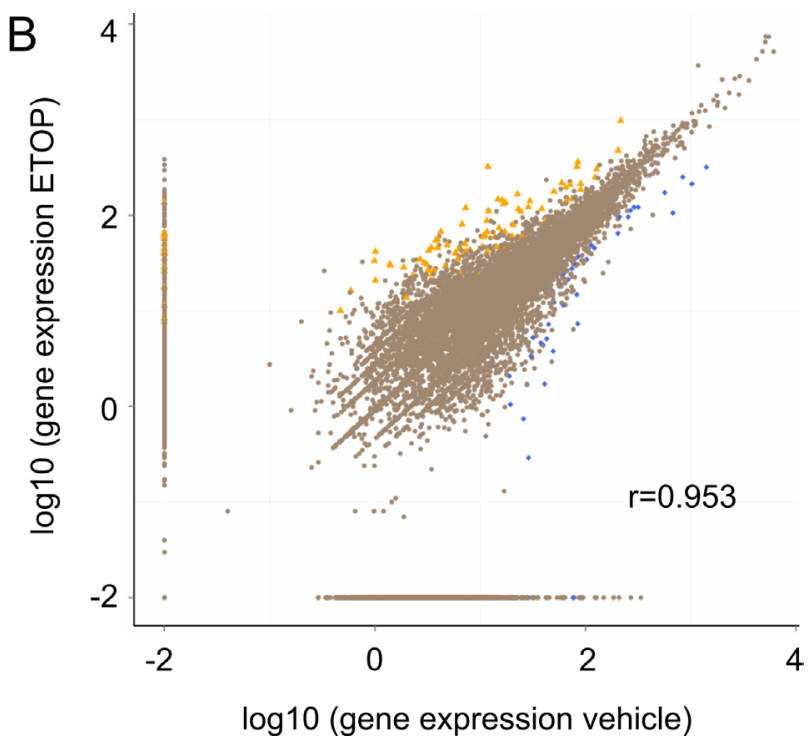

Figure 1: Global gene expression under ETOP-induced DNA damage. (A) MCF7 cells were treated with either vehicle (DMSO or 0$)$ or ETOP $(25 \mu \mathrm{M})$ for the indicated period of time, followed by Western blot examination for CHK2 phosphorylation at threonine 68 (CHK2pT68), CHK2, $\gamma \mathrm{H} 2 \mathrm{AX}$, and H2AX. (B) MCF7 cells were treated with vehicle or ETOP $(25 \mu \mathrm{M})$ for 2 hours, followed by RNA sequencing analysis. Transcripts were quantified as FPKM. The number of transcript pairs (vehicle vs ETOP) was 12,324. The correlation coefficient (r) was indicated. Differentially expressed genes (DEGs) were defined as $\log 2$ ratio of ETOP/vehicle $\geq 1$ and FDR $\leq 0.001$. The number of upregulated transcripts (yellow triangles) is $n=96$; the number of downregulated DEGs (blue squares) is $n=41$. 
upregulation of a well-established p53 target p21 $1^{\mathrm{CIP} 1}$ encoded by the CDKN1A gene in ETOP-treated MCF7 cells $[39,54]$. As expected, upregulation of CDKN1A $(\log 2$ ratio $=2.5, p=0.0068$, and FDR $=0.106)$ is defined at $p<0.05$ (Supplementary Table 4). MDM2 is also a p53 target induced by IR $[22,23,55]$, and was upregulated $(\log 2$ ratio $=1.08, p=0.0008$, and FDR $=0.026)$ in ETOP-treated MCF7 cells under the relax condition of FDR $<0.05$ (Supplementary Table 2).

With the largest set of DEGs defined $(\log 2$ ratio $\geq 1$, $p<0.05$; Supplementary Tables 4,5 ), we performed gene set and pathway enrichment analyses using the GAGE and
Reactome packages in $\mathrm{R}[56,57]$. The gene sets used in these analyses were derived from the GO term group (go. sets.hs). Analyses using the Gage package in $\mathrm{R}$ identified upregulations in ETOP-treated MCF7 cells in gene sets regulating Ras GTPase, RNA binding, response to organic substance, cytokine-mediated signaling pathway, kinase regulatory activity, protein binding, positive regulation of neurogenesis, and alcohol biosynthesis process (Table 2). Detail changes in the gene sets regulating Ras GTPase, RNA binding, cytokine-mediated signaling pathway, protein binding, and alcohol biosynthesis process are illustrated (Figure 3A-3E). The respective gene components in these
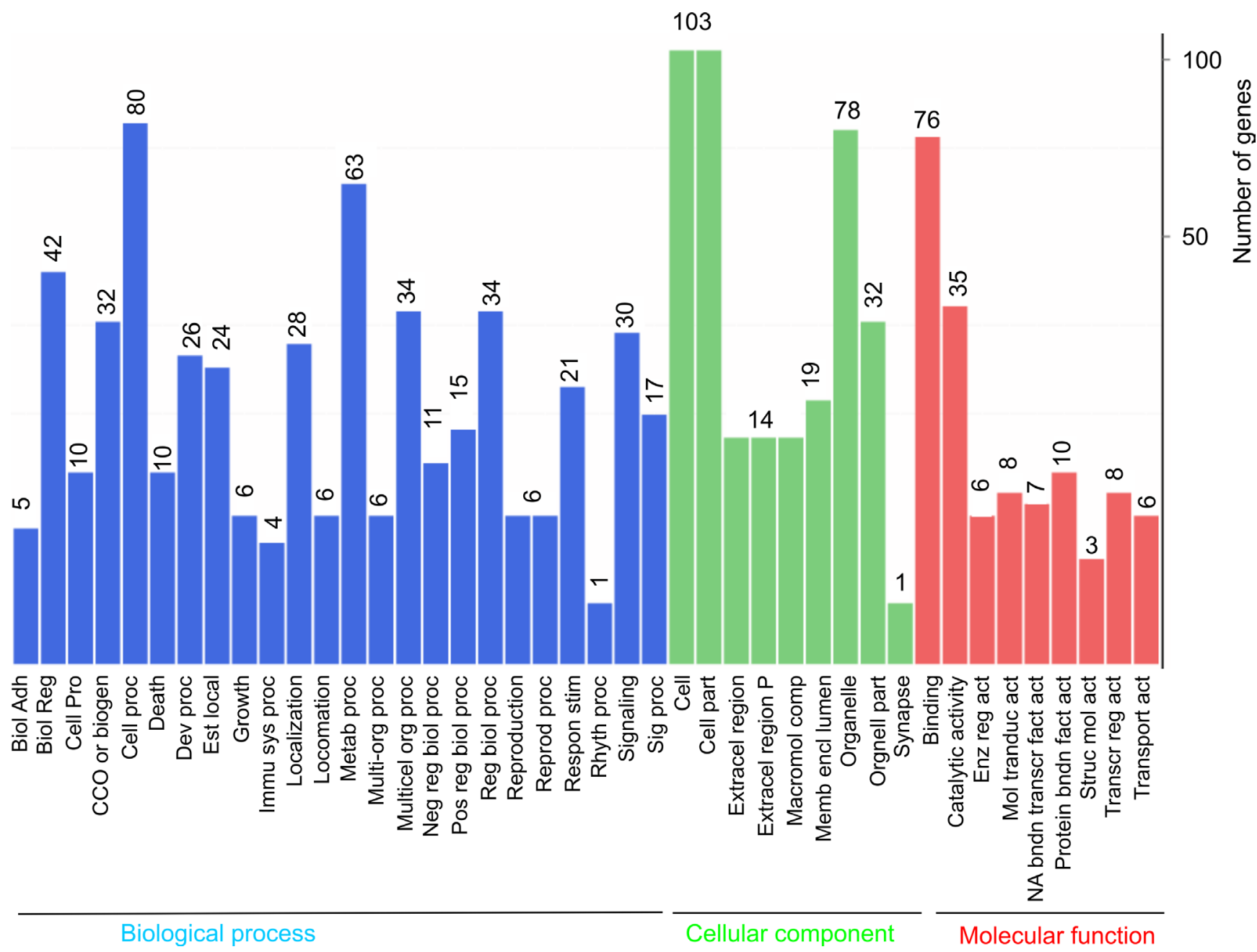

Figure 2: Gene ontology enrichment analysis of DEGs. DEGs described in Figure 1 legend were analyzed for enrichment in three GO ontologies: biological process, cellular component, and molecular function. The number of genes enriched in individual GO terms is indicated on top of the individual bars. Biol Adh: biological adhesion; Biol reg: biological regulation; Cell pro: cell proliferation; CCO or biogen: cellular component organization or biogenesis; Cell proc: cellular process; Dev proc: developmental process; Est local: establishment of localization; Immu sys proc: immune system process; Metab proc: metabolic process; Multi-org proc: multi-organism process; Multicel org proc: multicellular organismal process; Neg reg biol proc: negative regulation of biological process; Pos reg biol proc: positive regulation of biological process; Reg biol proc: regulation of biological process; Reprod proc: reproductive process; Respon stim: response to stimulus; Rhyth proc: rhythmic process; Sig proc: signaling process; Extracel region: extracellular region; Extracel region P: extracellular region part; Macromol comp: macromolecular complex; Memb encl lumen: membrane-enclosed lumen; Enz reg act: enzymatic regulator activity; Mol transduct act: molecular transducer activity; NA bndn transcr fact act: nucleic acid binding transcription factor activity; Protein bndn fact act: protein binding factor activity; Struc mol act: structural molecule activity; Transcr reg act: transcription regulator activity; and Transport act: transporter activity. 
gene sets are included (Supplementary Tables 6-14). ETOP treatment also led to downregulations of gene sets regulating clathrin-coated vesicle, calmodulin binding, microtubulebased movement, and coated vesicle (Table 2; Figure 3F-3I; Supplementary Tables 15-18).

In comparison to vehicle treatment, analysis using Reactome revealed alterations in multiple aspects of translation in ETOP-treated MCF7 cells (Table 2;
Supplementary Table 19). Alterations in these pathways and their enrichment factors are documented (Figure 4). The network nature of individual genes contributing to these enriched pathways is also demonstrated (Figure 5). Regulation of translation in DDR has been reported through selectively excluding and recruiting mRNA species to polysomes $[11,12]$. Our research suggests that control of translation in DDR could also be occurred at the transcription
A

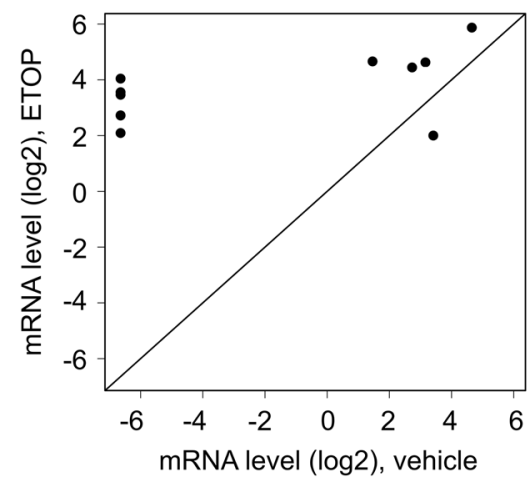

D

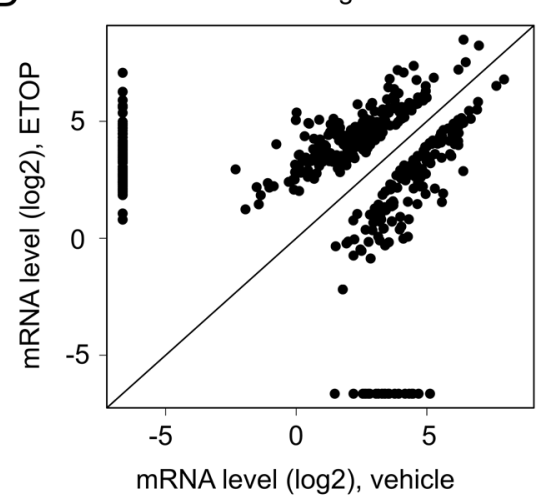

G

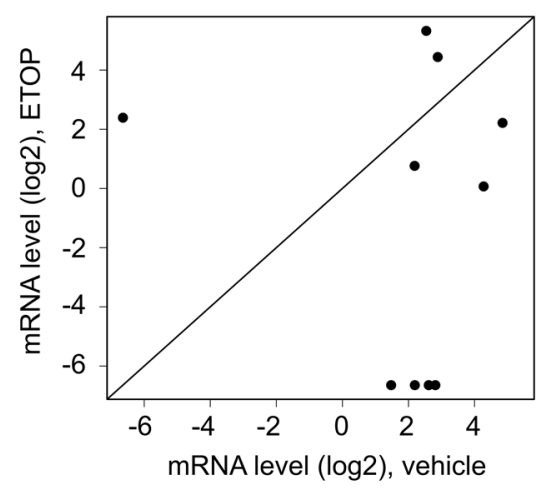

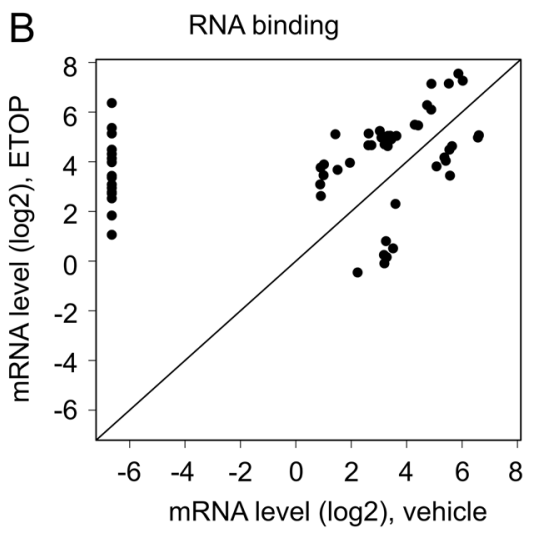

E Alcohol biosynthesis process

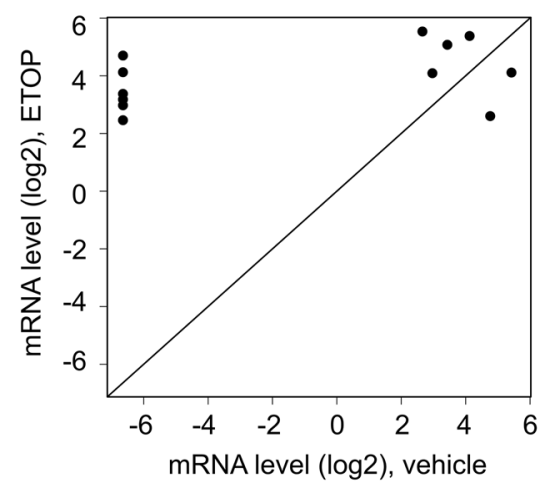

$\mathrm{H} \quad$ Microtubule-based movement

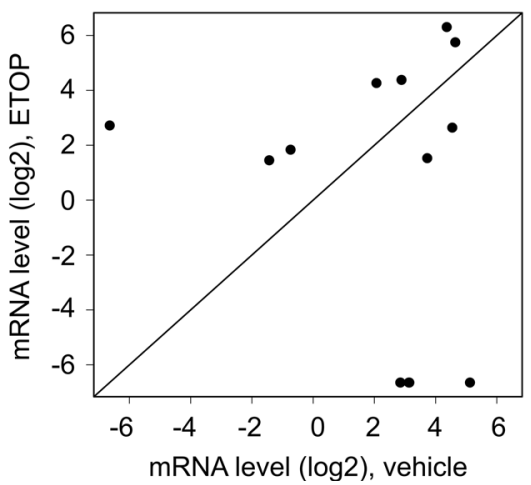

C Cytokine-mediated signaling pathway

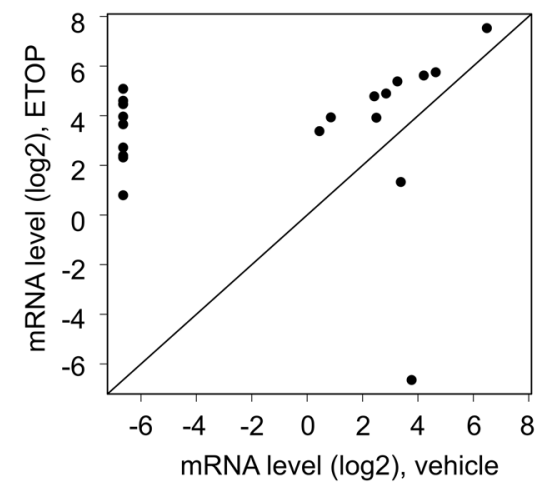

F

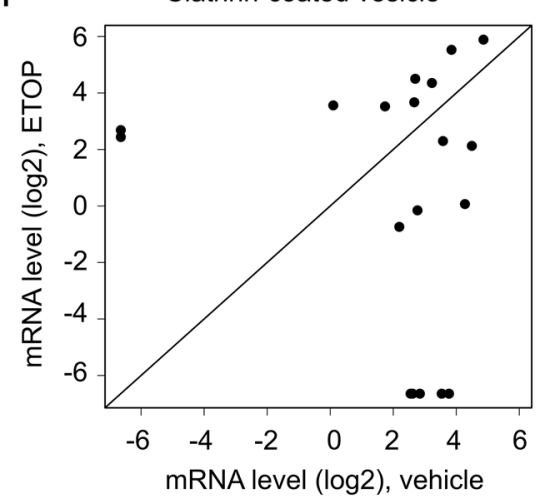

I

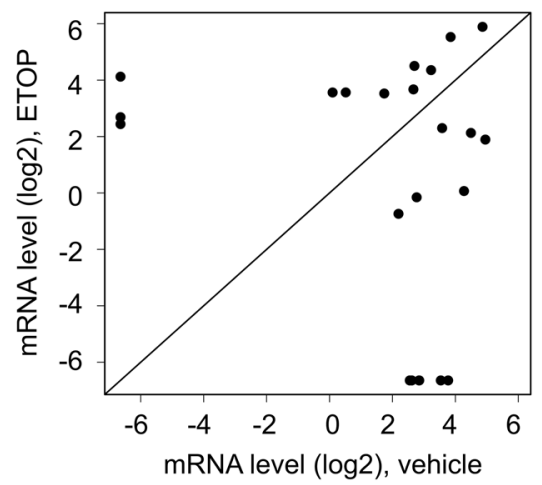

Figure 3: Alterations in gene expression in the enriched gene sets. Enrichment analysis for those DEGs defined as $p<0.05$ (Supplementary Table 4) was performed using the GAGE package in R [56]. Scatter plots show alterations in gene expression for individual genes in the upregulated gene sets $(\mathbf{A}-\mathbf{E})$ and downregulated gene sets $(\mathbf{F}-\mathbf{I})$. Gene expression was quantified as log2 units. See Supplementary Tables 6-18 for the individual gene sets. 
Table 1: Down-regulated genes in ETOP-treated MCF7 cells ${ }^{1}$

\begin{tabular}{|c|c|c|c|c|}
\hline Gene & locus & Log2 Ratio & $P$ value & FDR \\
\hline TCEB3CL & $18 \mathrm{q} 21.1$ & -12.89 & $2.27 \mathrm{E}-09$ & $4.31 \mathrm{E}-07$ \\
\hline CTAGE15 & $7 \mathrm{q} 35$ & -11.47 & $7.42 \mathrm{E}-06$ & 0.000602 \\
\hline PLGLB1 & $2 \mathrm{p} 11.2$ & -11.28 & 7.42E-06 & 0.000598 \\
\hline MFAP5 & $12 \mathrm{p} 13.31$ & -6.63 & $1.70 \mathrm{E}-06$ & 0.000193 \\
\hline TSPAN11 & $12 \mathrm{p} 11.21$ & -5.12 & $1.04 \mathrm{E}-09$ & $2.04 \mathrm{E}-07$ \\
\hline MRPS31P5 & $13 \mathrm{q} 14.3$ & -4.57 & $1.88 \mathrm{E}-07$ & 2.63E-05 \\
\hline GRIN1 & $9 q 34.3$ & -4.20 & $9.32 \mathrm{E}-06$ & 0.000718 \\
\hline CPLX1 & $4 \mathrm{p} 16.3$ & -3.71 & 2.11E-06 & 0.00023 \\
\hline RIMS1 & $6 q 13$ & -3.52 & $3.92 \mathrm{E}-27$ & $6.05 \mathrm{E}-24$ \\
\hline CHN2 & $7 \mathrm{p} 14.3$ & -3.18 & $5.66 \mathrm{E}-06$ & 0.000502 \\
\hline SLC9A8 & $20 q 13.13$ & -3.18 & $5.66 \mathrm{E}-06$ & 0.000499 \\
\hline TM4SF18 & $3 q 25.1$ & -3.17 & $3.01 \mathrm{E}-06$ & 0.000304 \\
\hline PROB1 & $5 q 31.2$ & -3.07 & $5.82 \mathrm{E}-07$ & $7.63 \mathrm{E}-05$ \\
\hline LCORL & $4 p 15.31$ & -3.03 & $1.08 \mathrm{E}-06$ & 0.000132 \\
\hline MTRNR2L10 & $\mathrm{Xp} 11.21$ & -2.68 & $6.18 \mathrm{E}-28$ & $1.27 \mathrm{E}-24$ \\
\hline SUPT20HL1 & Xp22.11 & -2.63 & $1.26 \mathrm{E}-05$ & 0.000927 \\
\hline LRRC8E & $19 \mathrm{p} 13.2$ & -2.59 & $1.26 \mathrm{E}-05$ & 0.000933 \\
\hline TSEN54 & $17 \mathrm{q} 25.1$ & -2.48 & $1.44 \mathrm{E}-06$ & 0.000166 \\
\hline KGFLP2 & $9 \mathrm{p} 12$ & -2.41 & $1.91 \mathrm{E}-10$ & 4.37E-08 \\
\hline FMN1 & $15 \mathrm{q} 13.3$ & -2.29 & 4.35E-06 & 0.0004 \\
\hline MTRNR2L8 & $11 \mathrm{p} 15.4$ & -2.27 & $5.12 \mathrm{E}-39$ & $2.10 \mathrm{E}-35$ \\
\hline FGF2 & $4 \mathrm{q} 28.1$ & -2.16 & $2.24 \mathrm{E}-06$ & 0.000238 \\
\hline MTRNR2L2 & $5 q 14.1$ & -2.14 & $3.64 \mathrm{E}-40$ & $2.25 \mathrm{E}-36$ \\
\hline LRRC37A2 & $17 \mathrm{q} 21.31$ & -2.03 & $3.76 \mathrm{E}-08$ & $6.02 \mathrm{E}-06$ \\
\hline MTRNR2L1 & $17 \mathrm{p} 11.2$ & -1.74 & $8.59 \mathrm{E}-28$ & $1.51 \mathrm{E}-24$ \\
\hline PFN1P2 & $1 \mathrm{p} 11.2$ & -1.72 & 4.60E-23 & $5.15 \mathrm{E}-20$ \\
\hline DMTF1 & $7 q 21.12$ & -1.68 & $5.67 \mathrm{E}-06$ & 0.000492 \\
\hline speedy hom E8, pseudo ${ }^{2}$ & NA & -1.65 & $1.09 \mathrm{E}-12$ & $3.94 \mathrm{E}-10$ \\
\hline TOX4 & $14 \mathrm{q} 11.2$ & -1.57 & $7.73 \mathrm{E}-10$ & $1.59 \mathrm{E}-07$ \\
\hline ZNF710 & $15 q 26.1$ & -1.56 & $7.26 \mathrm{E}-06$ & 0.000593 \\
\hline DNAJC18 & $5 q 31.2$ & -1.43 & $3.40 \mathrm{E}-07$ & $4.60 \mathrm{E}-05$ \\
\hline RHOQ & $2 \mathrm{p} 21$ & -1.41 & $7.32 \mathrm{E}-10$ & $1.53 \mathrm{E}-07$ \\
\hline HAS3 & $16 \mathrm{q} 22.1$ & -1.41 & $6.36 \mathrm{E}-06$ & 0.000529 \\
\hline FLJ31306 & $\# \mathrm{~N} / \mathrm{A}$ & -1.38 & $4.80 \mathrm{E}-13$ & $1.79 \mathrm{E}-10$ \\
\hline ICMT & $1 \mathrm{p} 36.31$ & -1.35 & $1.35 \mathrm{E}-05$ & 0.000976 \\
\hline TSHZ2 & $20 \mathrm{q} 13.2$ & -1.31 & $4.37 \mathrm{E}-14$ & $2.00 \mathrm{E}-11$ \\
\hline LOC100133286 & $21 \mathrm{q} 22.12$ & -1.26 & $9.27 \mathrm{E}-06$ & 0.000718 \\
\hline URAHP & $16 \mathrm{q} 24.3$ & -1.25 & 5.95E-06 & 0.000502 \\
\hline EMILIN3 & $20 \mathrm{q} 12$ & -1.23 & $1.02 \mathrm{E}-06$ & 0.000125 \\
\hline TSR1 & $17 \mathrm{p} 13.3$ & -1.19 & $2.62 \mathrm{E}-06$ & 0.000269 \\
\hline SYNC & $1 \mathrm{p} 35.1$ & -1.14 & 2.97E-09 & $5.47 \mathrm{E}-07$ \\
\hline
\end{tabular}

1: The candidates were selected based on $\log 2$ ratio (ETOP/vehicle) $\leq-1$ and FDR $\leq 0.001$.

2: speedy homolog E8 (Xenopus laevis), pseudogene; unable to locate its locus (NA). 
Table 2: Alteration of gene sets and pathways in ETOP-DEGs ${ }^{\mathrm{a}}$

\begin{tabular}{|c|c|c|}
\hline Gene sets & Set size ${ }^{\mathrm{d}}$ & $p$-value \\
\hline GO:0032318 regulation of Ras GTPase activity ${ }^{b}$ & 11 & 0.0313 \\
\hline GO:0003723 RNA binding ${ }^{b}$ & 59 & 0.0391 \\
\hline GO:0010033 response to organic substance ${ }^{b}$ & 125 & 0.0399 \\
\hline GO:0019221 cytokine-mediated signaling pathway ${ }^{\mathrm{b}}$ & 20 & 0.0423 \\
\hline GO:0019207 kinase regulator activity ${ }^{\mathrm{b}}$ & 12 & 0.0445 \\
\hline GO:0071310 cellular response to organic substance ${ }^{b}$ & 88 & 0.0499 \\
\hline GO:0005515 protein binding ${ }^{\mathrm{b}}$ & 491 & 0.0503 \\
\hline GO:0050769 positive regulation of neurogenesis ${ }^{b}$ & 12 & 0.0504 \\
\hline GO:0046165 alcohol biosynthetic process ${ }^{\mathrm{b}}$ & 12 & 0.0506 \\
\hline R-HSA-72613: Eukaryotic Translation Initiation ${ }^{\mathrm{b}}$ & 20 & 0.0202 \\
\hline R-HSA-72737: Cap-dependent Translation Initiation ${ }^{\mathrm{b}}$ & 20 & 0.0202 \\
\hline R-HSA-72702: Ribosomal scanning and start codon recognition ${ }^{\mathrm{b}}$ & 13 & 0.0202 \\
\hline R-HSA-72706: GTP hydrolysis and joining of the $60 \mathrm{~S}$ ribosomal subunit ${ }^{\mathrm{b}}$ & 19 & 0.0202 \\
\hline R-HSA-72649: Translation initiation complex formation ${ }^{\mathrm{b}}$ & 13 & 0.0202 \\
\hline $\begin{array}{l}\text { R-HSA-72662: Activation of the mRNA upon binding of the cap-binding } \\
\text { complex and eIFs, and subsequent binding to } 43 \mathrm{~S}^{\mathrm{b}}\end{array}$ & 13 & 0.0202 \\
\hline R-HSA-72766: Translation ${ }^{\mathrm{b}}$ & 23 & 0.0202 \\
\hline $\begin{array}{l}\text { R-HSA-156827: L13a-mediated translational silencing of Ceruloplasmin } \\
\text { expression }{ }^{\text {b }}\end{array}$ & 18 & 0.0362 \\
\hline $\begin{array}{l}\text { R-HSA-72695: Formation of the ternary complex, and subsequently, the } 43 \mathrm{~S} \\
\text { complex }\end{array}$ & 11 & 0.0449 \\
\hline GO:0030136 clathrin-coated vesicle ${ }^{c}$ & 19 & 0.0430 \\
\hline GO:0005516 calmodulin binding ${ }^{\mathrm{c}}$ & 10 & 0.0452 \\
\hline GO:0007018 microtubule-based movement ${ }^{\mathrm{c}}$ & 14 & 0.0471 \\
\hline GO:0030135 coated vesicle ${ }^{c}$ & 23 & 0.0495 \\
\hline
\end{tabular}

${ }^{a}$ enrichment in gene sets and pathways was performed using the GAGE and Reactome packages in $\mathrm{R}$

${ }^{b}$ the indicated gene sets were upregulated

cthe indicated gene sets were downregulated

dnumber of DEGs that are enriched in the individual gene sets

GO gene sets were produced using the GAGE package

R-HSA gene sets were resulted using the Reactome package.

level. Our observations are consistent with a recent RNA-seq analysis reporting alteration in translation in ETOP-treated mouse embryonic fibroblasts (MEFs) [58]. Taken together, the above observations revealed alterations in multiple pathways in MCF7 cells following ETOP treatment.

\section{Novel factors detected in ETOP-treated MCF7 cells}

To further examine these DEGs, we have selected a few genes to confirm their alterations. These candidates were selected based on the following criteria. 1) Their involvement in DDR is largely unknown. 2) They are within different groups of DEGs. RABL6 is a DEG defined under FDR $\leq 0.001$ (Supplementary Table 1) and RFTN2 upregulation appears in the DEG group of $p<0.05(\log 2$ ratio of $\mathrm{ETOP} /$ vehicle $=2.68, p=0.052$ ); the outcome would thus support our relax conditions used in the above analyses. 3) They potentially function in different processes (see later for details). Using real-time PCR, we demonstrated upregulations of RABL6 and RFTN2 (Figure 6A, 6B) and downregulation of TCEB3CL (Figure 6C).

We noticed the upregulation of several antisense (AS) RNA species in ETOP-treated cells (Supplementary Table 1). Since non-coding RNAs (ncRNAs) play critical roles in DDR regulation [32], we selected two AS species, one in the top (FAS-AS1) and another in the bottom (KMT2E-AS1) half of Supplementary Table 1, to examine their upregulation. As expected, real time PCR detected a robust FAS-AS1 upregulation (Figure 6D) and a significant KMT2E-AS1 increase (Figure 6E) following ETOP treatment.

To examine whether the above alterations in MCF7 cells treated with ETOP is cell line specific, we have 


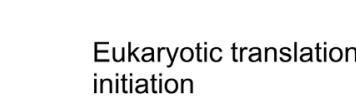

Cap-dependent translation initiation

Ribosomal scanning and start codon recognition

GTP hydrolysis and joining of the $60 S$ ribosomal subunit

Translation initiation complex formation

Activation of the mRNA upon binding of the cap-binding complex and elFs, and subsequent binding of $43 \mathrm{~S}$

Translation

L13a-mediated translational silencing of Ceruloplasmin expression

Formation of the ternary complex, and subsequently, the 435 complex

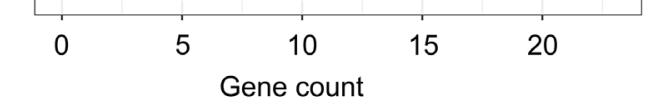

B

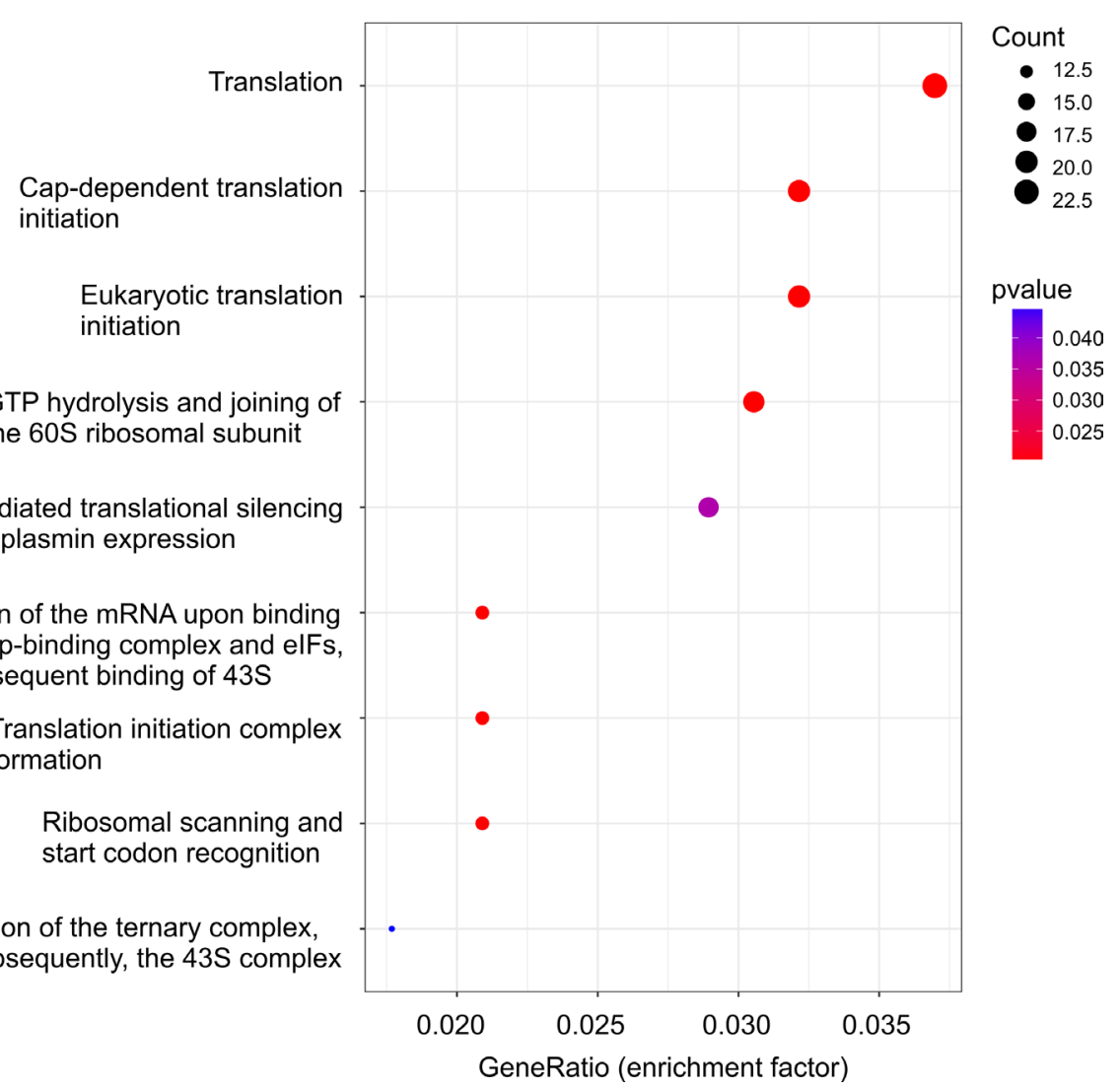

Figure 4: ETOP-induced DEGs are enriched in pathways regulating translation. Pathway enrichment on ETOP-induced DEGs ( $p<0.05$; Supplementary Table 4 ) was carried out using the Reactome package in R [57]. The enriched pathway (A) and the enrichment factor (GeneRatio) (B) are graphed. 
A

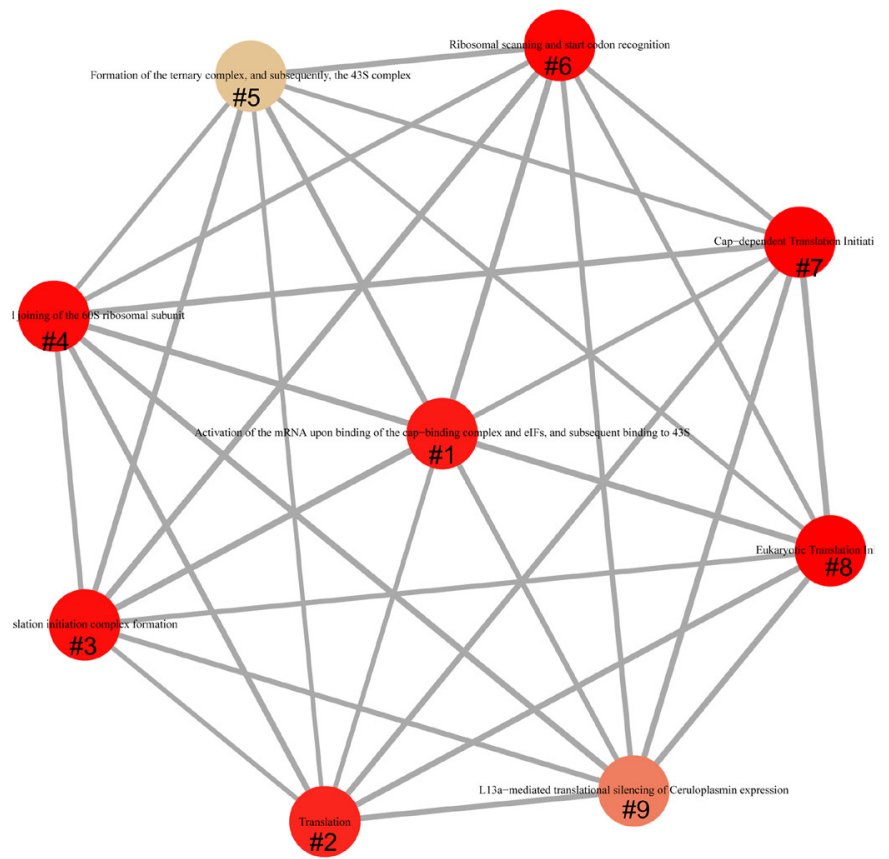

B

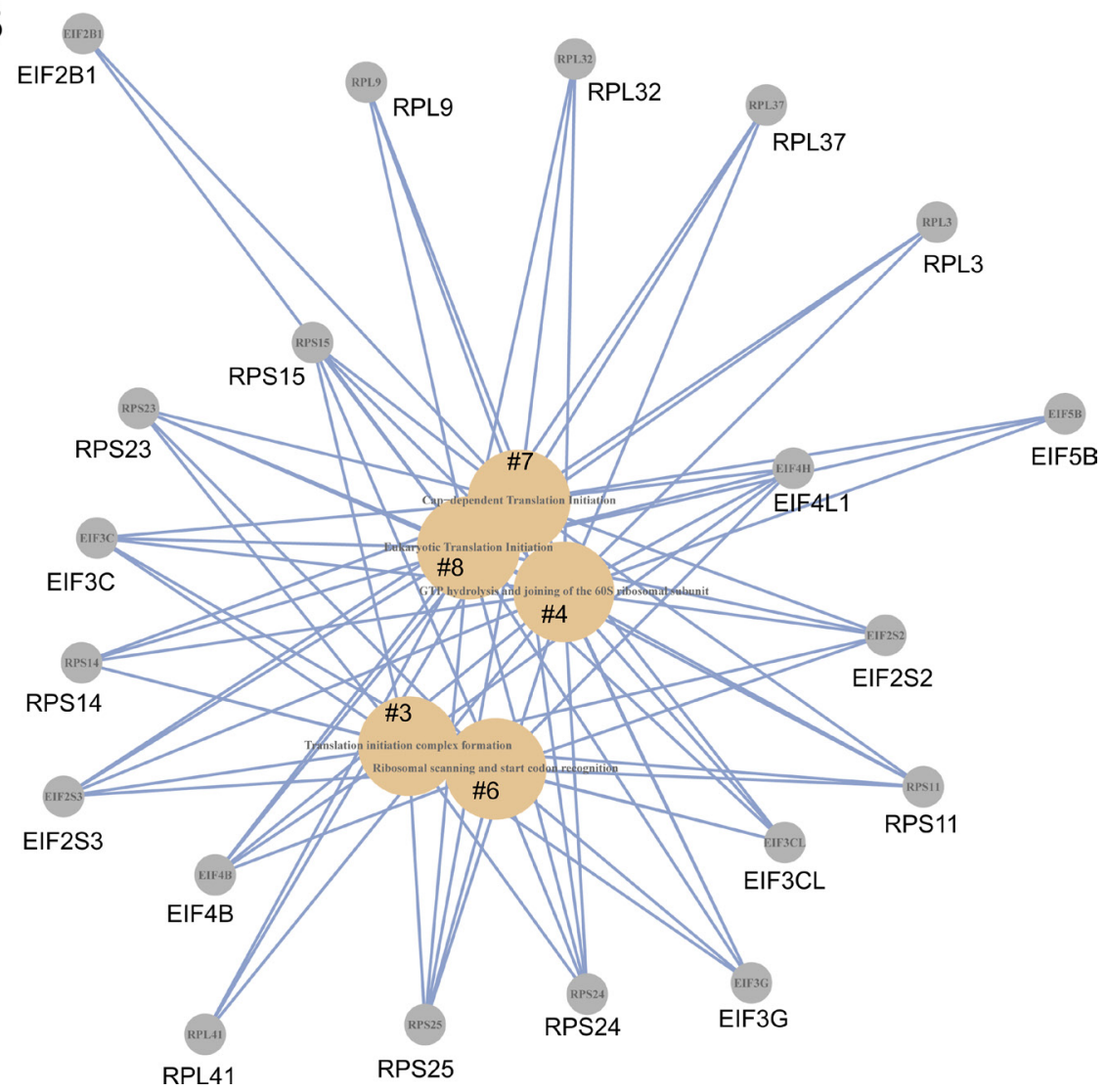

Figure 5: The network connection of the enriched pathways in protein translation. Pathway enrichment analysis was performed using Network map of the Reactome package in R [57] on DEGs $(p<0.05)$. (A) Network of the enriched pathways. (B) Individual enriched pathways and their contributing DEGs. \#1: Activation of the mRNA upon binding of the cap-binding complex and eIFs, and subsequent binding to 43S; \#2: Translation; \#3: Translation initiation complex formation; \#4: GTP hydrolysis and joining of the $60 \mathrm{~S}$ ribosomal subunit; \#5: Formation of the ternary complex, and subsequently, the 43S complex; \#6: Ribosomal scanning and start codon recognition; \#7: Cap-dependent Translation Initiation; \#8: Eukaryotic Translation Initiation; and \#9: L13a-mediated translational silencing of Ceruloplasmin expression. 
performed similar experiments using T47D breast cancer cells. First, ETOP at $25 \mu \mathrm{M}$ induced a plateau level of $\gamma \mathrm{H} 2 \mathrm{AX}$, indicative of a peak level of DSBs, along with the induction of CHK2 T68 phosphorylation following 2 hour treatment in T47D cells (Figure 7A). ETOP treatment significantly upregulated RABL6, RFTN2, and FAS-AS1 (Figure 7B, 7C, 7E) but not KMT2E-AS1 (data not shown), and significantly downregulated TCEB3CL (Figure 7D) in T47D cells.

RAS oncogene family-like 6 (RABL6, RBEL1, pp8875, and C9orf86) is a member of the Ras family of small GTPase (https://www.ncbi.nlm.nih.gov/gene/55684) with a potential oncogenic role in part via inactivating the Rb1 tumor suppressor [59-61]. Its involvement in DDR has yet to be demonstrated.

RFTN2 (raftlin family member 2) was upregulated in ETOP-treated MCF7 cells (Figure 6B) and T47D cells (Figure 7C). There is currently lack of evidence suggesting its physiological functions.

The physiological roles, including DDR, of TCEB3CL (transcription elongation factor B polypeptide 3C-like) remain unknown.

While the biology of KMT2E-AS1 has not been reported, FAS-AS1 has been studied and named as Saf
[62]. FAS-AS1 was demonstrated to protect T-lymphocytes and erythroblasts from FAS-induced apoptosis [62, 63], and has also been suggested to enhance FAS-mediated apoptosis in B-cell lympma by inhibiting the production of soluble FAS (sFAS) that prevents FAS-ligand from binding FAS [64]. More relevantly, upregulation of FAS-AS1 was reported following IR-induced DSBs [65]. Collectively, we provide the first evidence for a robust upregulation of FASAS1 following ETOP treatment, which may play a role in modulating ETOP-induced apoptosis in MCF7 cells.

\section{Dynamic alterations of transcription in MCF7 cells treated with ETOP}

RNA levels are affected by the rates of RNA synthesis and decay. To further determine whether the observed upregulation and downregulation of RNAs in ETOP-initiated DDR were attributable to RNA synthesis, we examined the rate of transcription of RABL6, RFTN2, TCEB3CL, FAS-AS1, and KMT2E-AS1 using the wellestablished 4-thiouridine (4sU)-based metabolic labeling system $[66,67]$. The advantage of this system includes that $4 \mathrm{sU}$ does not affect RNA synthesis even after $>24$ hour
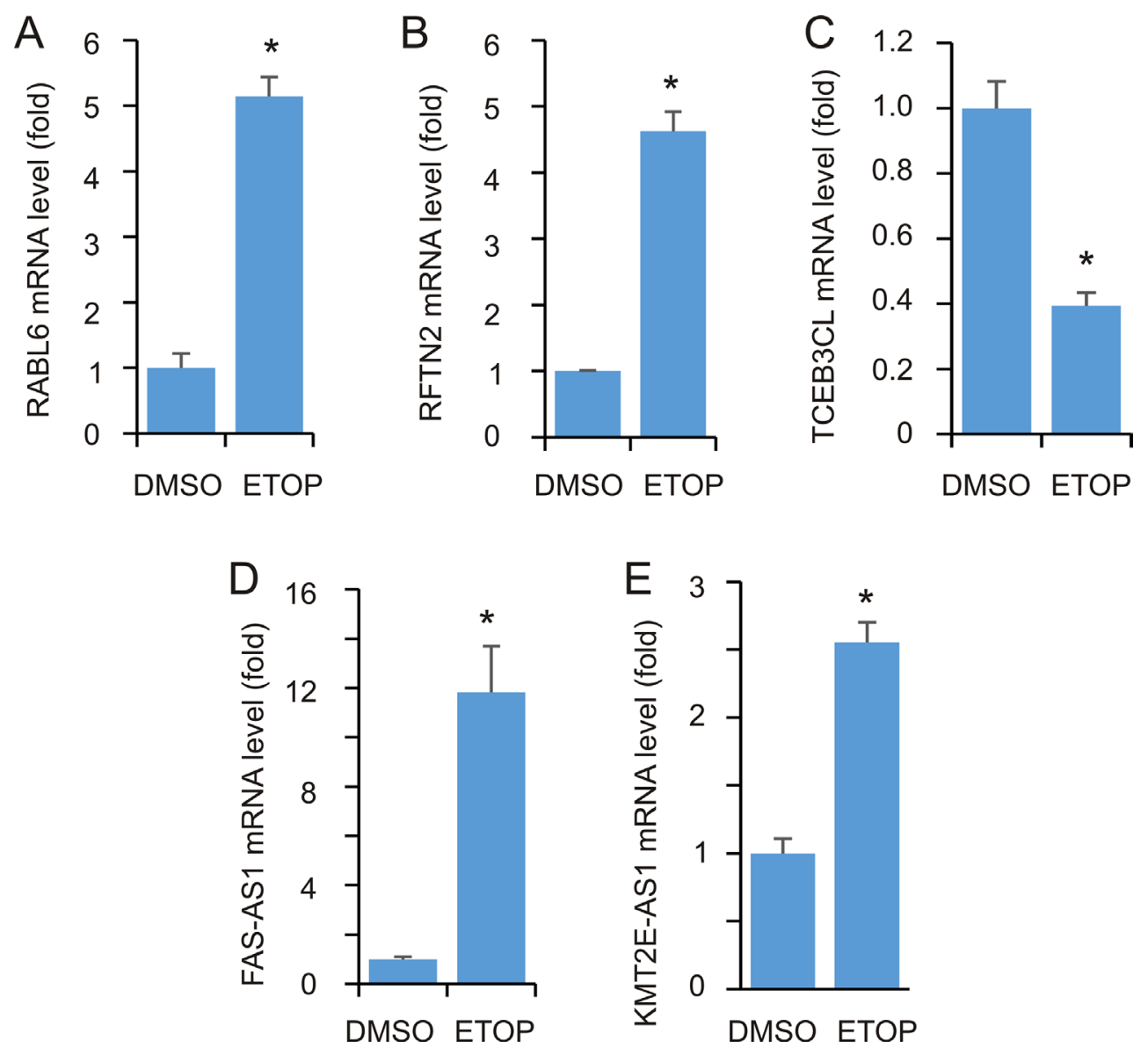

Figure 6: Real-time PCR analysis of DEGs. MCF7 cells were treated with either vehicle or ETOP for 2 hours, followed by realtime PCR analysis for the indicated genes. Actin was used as a control; the expression of individual transcripts were normalized to actin, and expressed as fold changes to the control treatment. Experiments were repeated three times; ${ }^{*}: p<0.05$ in comparison to the control treatments (2-tailed Student's $t$-test). 
exposure at high doses [66]. Following published conditions $[66,68,69]$, we performed a short duration (45 min) labelling covering $0.5 \mathrm{~h}, 15-60 \mathrm{~min}, 45 \mathrm{~min}-90 \mathrm{~min}$, and $75 \mathrm{~min}-120 \mathrm{~min}$ of ETOP treatment (Figure 8A), and were able to show a significant enhancement in the synthesis of RABL6, RFTN2, FAS-AS1, and KMT2E-AS1 (Figure 8B, $8 \mathrm{C}, 8 \mathrm{E}, 8 \mathrm{~F})$, while the rate of TCEB3CL RNA synthesis was reduced in certain periods during the duration of ETOP treatment in MCF7 cells (Figure 8D). Dynamic alterations in the transcription of these target genes except KMT2EAS1 were also demonstrated in T47D cells (Figure 8G-8J). These observations are in accordance with their alterations in the steady levels determined by RNA sequencing and real-time PCR analysis (Supplemntary Table 1 and Table 1; Figures 6 and 7). Collectively, these observations support the possibility that alterations in RNA levels during DDR are in part attributable to changes in gene transcription.

\section{DISCUSSION}

An intimate relationship between RNA biology and DDR has been suspected for many decades. Insights on this concept have recently been emerged $[19,31-33]$. An interesting aspect is the observed mutual impacts between transcription and DDR. The requirement of $\mathrm{DSB}$, at least for the estrogen receptor target pS2 promoter, in transcription and AIREmediated transcription were intriguing $[36,37]$. Recent development reveals a cross utilization of DNA damage repairing proteins as transcription factors and vice versa [70]. Despite these advances, our knowledge on the DDR-coupled transcription remains limited. DSBs initiate a local inhibition on transcription, a process that is regulated in part through BMI1-mediated histone ubiquitination [71]. However, whether DSBs and other DNA lesion types result in a global repression of transcription remains debating. We provide a unique analysis on DSBs induced by ETOP, and observe a high correlation coefficient 0.953 in more than 12,000 pairs of transcripts between vehicle-treated cells and ETOP-treated cells (Figure 1B). Thus, our and other's research $[28,72]$ does not support a global transcription suppression by DNA damage. While global transcription inhibition can be envisaged under massive DNA damage, maintenance of an active global transcription under situations in which DNA damage can be repaired is likely critical for cells to manage the complex requirements: DDR execution and exit. This concept is supported by DDR regulating stem cell properties [73], and DNA damage modulating gene expression in other settings [74, 75].

Nonetheless, DNA damages at least ETOPinitiated DSBs modulate the expression of a set of genes (Supplementary Table 1, Table 1, Supplementary Tables 2-5). These genes include RAD52 upregulation (Supplementary Table 4), which is in accordance with the reported RAD52 increase in HepG2 cells following ETOP treatment [76]. The pathways affected by ETOP-induced
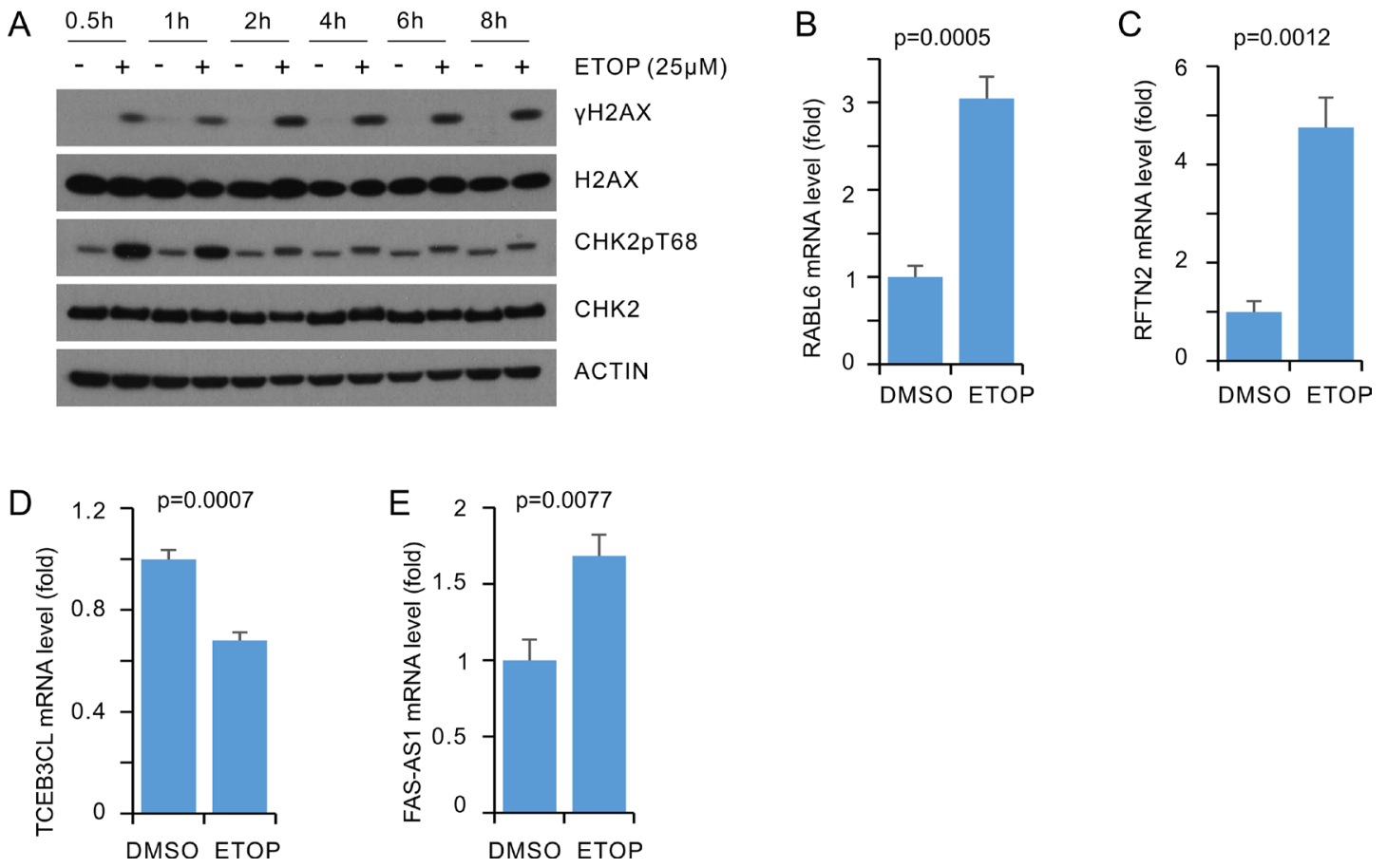

Figure 7: Real-time PCR analysis of DEGs in ETOP treated T47D cells. T47D cells were treated with either vehicle or ETOP for 2 hours, followed by real-time PCR analysis for the indicated genes. Actin was used as a control; the expression of individual transcripts were normalized to actin, and expressed as fold changes to the control treatment. Experiments were repeated three times; ${ }^{*}: p<0.05$ in comparison to the control treatments (2-tailed Student's $t$-test). 
differentially expressed genes are enriched in multiple processes and pathways that do not apparently relate to DNA lesion repair or checkpoint activation (Figures 2-5;
Supplementary Tables 6-19). For example, the translation process is enhanced in ETOP-treated MCF7 cells (Table 2); RNA-seq analysis of MEFs treated with ETOP has
A

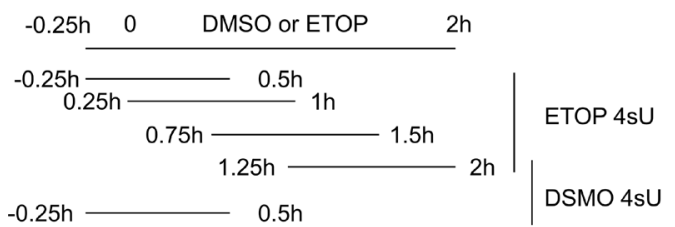

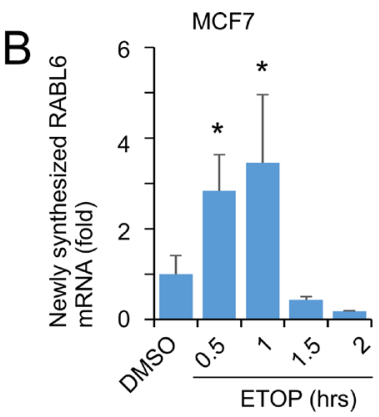
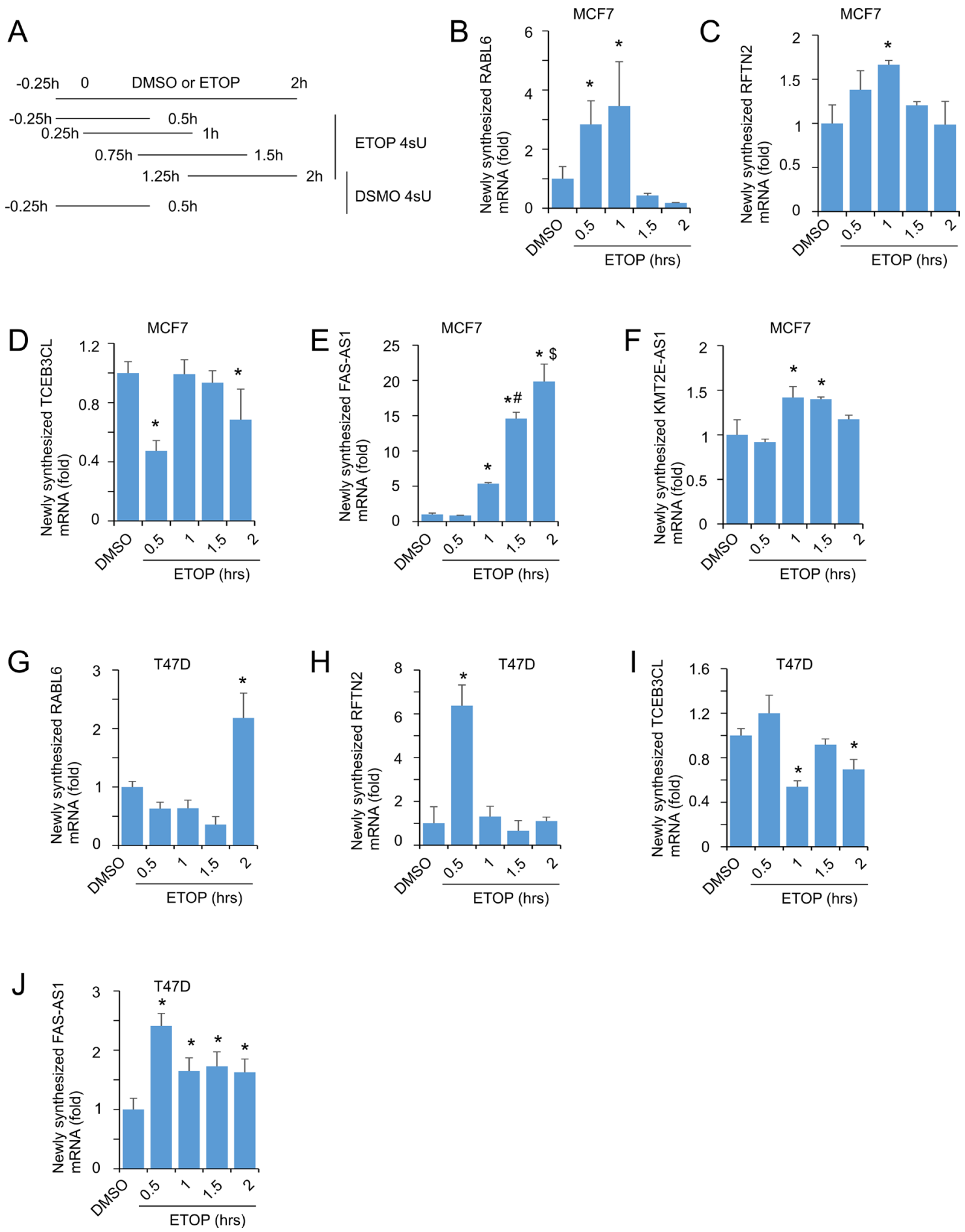

Figure 8: Alterations in RNA synthesis during DDR. (A) Outline of a short term of metabolic labeling. DMSO and ETOP treated cells were labeled with $4 \mathrm{sU}$ at $250 \mu \mathrm{M}$ for 45 minutes as indicated. (B-J) Pre-existing RNA and newly synthesized (4sU-labelled) RNA was isolated and analyzed for the indicated transcripts. The human large 60S ribosomal protein L110E (H36B4) was used an internal control. The average levels of newly synthesized RNA in two periods of DMSO treatments (A) were used to compare to the rates of RNA synthesis for the indicated genes under ETOP treatment. All real time PCR reactions have normalized to H36B4. Experiments were repeated three times; means \pm SD are graphed. ${ }^{*} p<0.05$ in comparison to DMSO; ${ }^{*} p<0.05$ compared to ETOP $1 \mathrm{~h} ;{ }^{\$} p<0.05$ in compared to ETOP 1.5 h. Statistical analyses were performed using Student's $t$-test (2-tailed). 
also reported alteration in translation [58]. The biology of changes in translation in cells treated with ETOP is likely complex; future research will need to address this issue.

It remains largely unclear as to why the expression of selective genes is downregulated except for the reason to avoid complication with DNA damage repair. In contrast, evidence supports the concept that gene upregulation is to ensure the expression of DNA repair genes, a process in which p53 plays a role [33, 77]. However, IR also results in gene upregulation independent of p53 [30]. Collectively, our research together with the published evidence supports a much broad alteration in gene expression and a broad contribution of these alterations in the facilitations of cell fate selection under DNA damage. While these changes in RNA abundance can be attributable to alterations in the rates of RNA decay, our study using a limited number of genes (Figure 8) revealed a contribution of changes in RNA synthesis to the steady level of RNA during DDR. However, it should be stressed that our research does not exclude an impact RNA decay on RNA abundance in cells undergoing DDR.

The contributions of RNA to DDR is not limited to protein-coding mRNA. Noncoding RNAs (ncRNAs) are emerging as a critical regulator of DDR [31, 32], a development that fits well with the current knowledge that while approximately $70 \%$ of human genome is transcribed into RNAs, no more than $2 \%$ of the genome is for protein coding mRNAs [78]. Long noncoding (lncRNA) LINP1 enhances DSB repair through non-homologous end joining (NHEJ) [79]. While p53 inhibits LINP1 [79], p53 induces the production of lncRNA PANDA from the CDKN1A promoter in response to doxorubicin-induced DSB, and PANDA reduces the expression of pro-apoptotic factors [80]. Similar to the action of doxorubicin in poisoning topoisomerase II, we observed that ETOP also induces a set of ncRNAs, including FAS-AS1, KMT2E-AS1 (Supplementary Table 1; Figure 6D, 6E), SPTY2D1AS1, and PSMD6-AS2 (Supplementary Table 1). FASAS1 regulates FAS-induced apoptosis [62-64], and is induced by IR through the action of ATM [65], a study that validates our work here. ETOP treatment also caused a downregulation of ncRNA Speedy hom E8 pseudogene (Table 1). While the physiological roles of these ncRNAs are unknown, it will be interesting to investigate their contributions to DDR. Since our studies are based on p53 wild type MCF7 cells, the contributions of p53 to the alterations of these genes could be studied in future.

In addition to our study using MCF7 cells, RNAseq has been used to analyze ETOP-treated HEK293 [37], MEFs [58], and fetal liver-derived hematopoietic stem cells (FL-HSC) [81] for different purposes. While ETOP treatment activates the MAPK, WNT, JAK-STAT, SHH, and NOTCH pathways in FL-HSC [81], ETOP exposure alters the translation process [58] which is in line with our study. Nonetheless, our study represents a pioneer effort to directly address the global RNA expression in
ETOP-induced DNA damage using the state-of-the-art RNA sequencing technology. However, our study should be cautiously interpreted. While ETOP induces DSBs, whether our observations here apply to cells undergoing DSBs induced by other genotoxic treatments should be investigated in the future.

While the current study focuses on ETOP-induced DDR, some alterations may also apply to other types of DDR. In supporting this possibility, we have detected the same changes in a limited number of genes in MCF7 cell treated with either ETOP or hydroxurea (HU, our unpublished observations). ETOP induces DDR via the production of DSBs and HU causes DDR via the induction of single strand DNA lesions [82, 83]. This commonality, nonetheless, is expected as DSBs and single strand DNA lesions co-occur in different DDR settings. However, unique pathways and DEGs are certainly expected in different types of DDR and in different types of cells. This area certainly deserves further investigations.

\section{MATERIALS AND METHODS}

\section{Cell culture and DNA damage induction}

MCF7 and T47D cells were purchased from American Type Culture Collection (ATCC; Manassas, VA), and cultured in DMEM supplemented with $10 \%$ Foetal Bovine Serum (FBS; Sigma Aldrich; Oakville, ON) and 1\% Penicillin-Streptomycin (Life Technologies; Burlington, ON). Etoposide (ETOP) was obtained from Sigma. For induction of DSBs, cells were treated with either ETOP at $25 \mu \mathrm{M}$ or vehicle (DMSO, 1:1000 dilution) for 2 hours.

\section{Western blot analysis}

Western blot analysis was performed according to our established protocol [39, 54, 83-85]. Briefly, $50 \mu \mathrm{g}$ of total cell lysate protein was separated on a SDS-PAGE gel and transferred onto Amersham Hybond ECL nitrocellulose membranes (Amersham, Baie d'Urfe, QC). Blots were treated with $5 \%$ skim milk and incubated at $4{ }^{\circ} \mathrm{C}$ overnight with the following antibodies: anti-H2AX (1:1000, Santa Cruz), anti- $\gamma \mathrm{H} 2 \mathrm{AX}$ (1:1000, Upstate), anti-phosph-CHK2 (T68) (1:500, Cell Signaling), and anti-CHK2 (1:1000, Cell Signaling). The blots were then incubated with the specific HRP-conjugated secondary antibodies at room temperature for one hour, followed by developing signals using an ECL Western Blotting Kit (Amersham, Baie d'Urfe, QC).

\section{Real-time PCR analysis}

Total RNA was isolated using TRIzol (Life Technologies, Burlington, ON) following the manufacturers' instructions. Reverse transcription and qRT-PCR was carried out as previously described [86, 87]. 
Briefly, $2 \mu \mathrm{g}$ of RNA was converted to cDNA, followed by qRT-PCR, where $1 \mu \mathrm{L}$ of cDNA was used in each reaction. Real time PCR primers used were presented in Supplementary Table 20.

\section{RNA sequencing analysis}

RNA was extracted using mRNeasy Mini Kit (Qiagen, No. 217004) following the manufacturer's instructions. RNA-seq libraries were prepared using TruSeq Ribo Profile Mammalian Kit (Illumina, RPHMR12126) as per manufacturer's instructions, and sequenced by BGI using the HiSeq 4000 system. RNA sequences were quantified by BGI (http://www.genomics. $\mathrm{cn} /$ en/navigation/show_navigation?nid $=2657$ ).

The number of raw reads obtained was $18,222,960$ and 22,080,922 for vehicle and ETOP treated MCF7 cells, respectively. From raw reads, we removed the adaptor reads and low quality reads which were defined as reads containing more than $10 \%$ of unknown bases or reads consisting of $>50 \%$ of low quality reads. The clean reads obtained for the above two samples were respectively $99.97 \%$ and $99.96 \%$ of the individual raw reads, and were used to map to the HISAT reference genome [88] using the Bowtie2 alignment program [89]. Transcript quantification was performed using the RSEM program [90], and expressed as fragments per kilobase of exon per million fragments mapped (FPKM). FPKM was calculated based on the formula: $\mathrm{FPKM}=10^{6} \mathrm{C} /\left(\mathrm{NL} / 10^{3}\right)$, where $\mathrm{C}$ is the number of fragments aligned to a specific gene; $\mathrm{N}$ is the total number of fragment aligned to a gene; and $\mathrm{L}$ is the combined exon length (base number) of a gene. Therefore, FRKM is a normalized unit of transcript abundance, and can be used to compare gene expression among different genes. Clean reads have been deposited to NIH Sequence Read Archive (SRA) (access number: SRP104001).

\section{Screen for differentially expressed genes (DEGs)}

DEGs in the pair of vehicle vs ETOP was screened using the Poisson Distribution Method based on a strict algorithm that was developed by BGI (http://www. genomics.cn/en/navigation/show_navigation?nid = 2657) .

\section{Gene oncology (GO) enrichment analysis}

This analysis was performed to analyze enrichment in all three GO ontologies (molecular function, cellular component and biological process) for DEGs derived from the comparison of vehicle vs ETOP. We first mapped DEGs to the GO terms as defined in the database (http:// www.geneontology.org/), calculated gene numbers, and determined a significant enrichment using hypergeometric test. Significance $(p<0.05)$ was determined using Bonferroni Correction.

\section{Gene set and pathway enrichment analysis}

The GAGE [56] and Reactome [57] packages in $\mathrm{R}$ were used to analyze DEGs for gene set and pathway enrichment within the go.set.hs databases [56].

\section{Analysis of RNA synthesis using metabolic labelling}

MCF7 and T47D cells $\left(10^{6}\right)$ were labeling with 4-thiouridine $(4 \mathrm{sU})$ at $250 \mu \mathrm{M}$ for 45 minutes at the treatment conditions defined in Figure 8A. The dose and duration used was based on publications reporting that this condition produces a sufficient level of labeling and without noticeable interference with RNA synthesis in mammalian cells $[66,68,69]$. RNA was isolated using miRNeasy MinElute; 4sU-labeled (newly synthesized) RNA in a total of $20 \mu \mathrm{g}$ RNA was biotinylated using the EZ-Link Biotin-HPDP kit (Thermo Fisher Scientific) according the manufacturer's protocol. Briefly, RNA was heated at $65^{\circ} \mathrm{C}$ and cooled on ice, followed by incubation with EZ-link Biotin HPDP ( $2 \mathrm{mg} / \mathrm{ml}$ dissolved in dimethylformamide/ $\mathrm{DMF}$ ) at room temperature for 2 hours in a labeling buffer (10mM Tris $\mathrm{pH}$ 7.4, $1 \mathrm{mM}$ EDTA). Unbound BiotinHPDP was removed by chloroform/isoamylalcohol (24:1) extraction. RNA was precipitated using isopropanol and washed with $75 \%$ ethanol. GlycoBlue Coprecipitant (Life Tech, AM9516), $15 \mu \mathrm{g}$ was used as an RNA indicator. RNA was heated at $65^{\circ} \mathrm{C}$. Biotinylated RNA was captured using conjugated MyOne Streptavidin C1 Beads (20 $\mu l)$ (Invitrogen), which was prepared according to the manufacturer's instruction, at room temperature for 90 minutes. The streptavidin $\mathrm{C} 1$ beads were then washed using a buffer $(10 \mathrm{mM}$ TrisCl, pH7.5; $1 \mathrm{mM}$ EDTA; $1 \mathrm{M} \mathrm{NaCl})$ at $65^{\circ} \mathrm{C}$ for $1-2$ minutes three times. The unlabeled RNA was collected by pooling supernatants and three washes. The beads were further washed at room temperature twice. The biotin-labelled RNAs were eluded using $100 \mathrm{mM}$ dithiothreitol (DTT) at room temperature twice. The unlabeled RNAs and biotin-labelled RNAs were purified using RNeasy MiniElute Kits (Qiagen). RNAs were then used for $\mathrm{RT}$ and $\mathrm{qPCR}$ experiments.

\section{Statistical analysis}

Difference in gene expression screened by the Poisson Distribution Method was determined using the Bonferroni method. A $p$-value $<0.05$ was considered statistically significant. False discovery rate (FDR) [91] was calculated to correct both type I and type II errors. Student's $t$-test was used to analyze real time PCR data with $p<0.05$ being considered statistically significant.

\section{CONFLICTS OF INTEREST}

All authors declare no conflicts of interest. 


\section{FUNDING}

This work was supported by grants from Foundation of Shenzhen overseas high level talent innovation and entrepreneurship special funds project (Grant No. KQCX20120814150420241) to F.W.; The Natural Science Foundation of Guangdong Province (Grant No. 2014A030313749; Grant No. 2013010016559) to F.W.; The Natural Science Foundation of Heilongjiang Province (Grant No.C2015033) to F.W.; Foundation from District Science and technology innovation Bureau of Longgang Distract (Grant No. YLWS20140610155624914, 20170405102551652) to F.W.; Research Foundation of Guangdong Medical Science and Technology Research (Grant No. 2016118111251132 to F.W.; Foundation from Science and Technology Innovation Committee of Shenzhen (Grant No. JCYJ20150403094227974) to F.W.; Foundation from Science and Technology Innovation Committee of Shenzhen (Grant No. JCYJ20150403094227974) to F.W.; and Research Foundation of Guangdong medical science and Technology Research (Grant No. 2016118111251132) to F.W. This work was also supported in part by an award from Teresa Cascioli Charitable Foundation Research Award in Women's Health to D.T., and grants from Breast Cancer Foundation of Canada/the Canadian Cancer Society (grant \#: 319412) and Cancer Research Society to D.T.

\section{REFERENCES}

1. Zhou BB, Elledge SJ. The DNA damage response: putting checkpoints in perspective. Nature. 2000; 408:433-9. https://doi.org/10.1038/35044005.

2. Lin X, Yan J, Tang D. ERK kinases modulate the activation of PI3 kinase related kinases (PIKKs) in DNA damage response. Histol Histopathol. 2013; 28:1547-54.

3. Costanzo V, Shechter D, Lupardus PJ, Cimprich KA, Gottesman M, Gautier J. An ATR- and Cdc7-dependent DNA damage checkpoint that inhibits initiation of DNA replication. Mol Cell. 2003; 11:203-13.

4. Zou L, Elledge SJ. Sensing DNA damage through ATRIP recognition of RPA-ssDNA complexes. Science. 2003; 300:1542-8. https://doi.org/10.1126/science.1083430.

5. Smith J, Tho LM, Xu N, Gillespie DA. The ATM-Chk2 and ATR-Chk1 pathways in DNA damage signaling and cancer. Adv Cancer Res. 2010; 108:73-112. https://doi. org/10.1016/B978-0-12-380888-2.00003-0.

6. Cassimere EK, Mauvais C, Denicourt C. p27Kip1 Is Required to Mediate a G1 Cell Cycle Arrest Downstream of ATM following Genotoxic Stress. PLoS One. 2016; 11:e0162806. https://doi.org/10.1371/journal.pone.0162806.

7. Paulsen RD, Soni DV, Wollman R, Hahn AT, Yee MC, Guan A, Hesley JA, Miller SC, Cromwell EF, Solow-Cordero DE, Meyer T, Cimprich KA. A genome-wide siRNA screen reveals diverse cellular processes and pathways that mediate genome stability. Mol Cell. 2009; 35:228-39. https://doi. org/10.1016/j.molcel.2009.06.021.

8. Guleria A, Chandna S. ATM kinase: Much more than a DNA damage responsive protein. DNA Repair (Amst). 2016; 39:1-20. https://doi.org/10.1016/j.dnarep.2015.12.009.

9. Dan Dunn J, Alvarez LA, Zhang X, Soldati T. Reactive oxygen species and mitochondria: A nexus of cellular homeostasis. Redox Biol. 2015; 6:472-85. https://doi. org/10.1016/j.redox.2015.09.005.

10. Mahajan K, Mahajan NP. Cross talk of tyrosine kinases with the DNA damage signaling pathways. Nucleic Acids Res. 2015; 43:10588-601. https://doi.org/10.1093/nar/gkv1166.

11. Lu X, de la Pena L, Barker C, Camphausen K, Tofilon PJ. Radiation-induced changes in gene expression involve recruitment of existing messenger RNAs to and away from polysomes. Cancer Res. 2006; 66:1052-61. https://doi. org/10.1158/0008-5472.CAN-05-3459.

12. Powley IR, Kondrashov A, Young LA, Dobbyn HC, Hill K, Cannell IG, Stoneley M, Kong YW, Cotes JA, Smith GC, Wek R, Hayes C, Gant TW, et al. Translational reprogramming following UVB irradiation is mediated by DNA-PKcs and allows selective recruitment to the polysomes of mRNAs encoding DNA repair enzymes. Genes Dev. 2009; 23:1207-20. https://doi.org/10.1101/gad.516509.

13. Kumaraswamy S, Chinnaiyan P, Shankavaram UT, Lu X, Camphausen K, Tofilon PJ. Radiation-induced gene translation profiles reveal tumor type and cancer-specific components. Cancer Res. 2008; 68:3819-26. https://doi. org/10.1158/0008-5472.CAN-08-0016.

14. Paronetto MP, Minana B, Valcarcel J. The Ewing sarcoma protein regulates DNA damage-induced alternative splicing. Mol Cell. 2011; 43:353-68. https://doi.org/10.1016/j. molcel.2011.05.035.

15. Savage KI, Gorski JJ, Barros EM, Irwin GW, Manti L, Powell AJ, Pellagatti A, Lukashchuk N, McCance DJ, McCluggage WG, Schettino G, Salto-Tellez M, Boultwood $\mathrm{J}$, et al. Identification of a BRCA1-mRNA splicing complex required for efficient DNA repair and maintenance of genomic stability. Mol Cell. 2014; 54:445-59. https://doi. org/10.1016/j.molcel.2014.03.021.

16. Kleiman FE, Manley JL. The BARD1-CstF-50 interaction links mRNA 3' end formation to DNA damage and tumor suppression. Cell. 2001; 104:743-53.

17. Mirkin N, Fonseca D, Mohammed S, Cevher MA, Manley JL, Kleiman FE. The 3' processing factor CstF functions in the DNA repair response. Nucleic Acids Res. 2008; 36:1792-804. https://doi.org/10.1093/nar/gkn005.

18. Wickramasinghe VO, Laskey RA. Control of mammalian gene expression by selective mRNA export. Nat Rev Mol Cell Biol. 2015; 16:431-42. https://doi.org/10.1038/ nrm4010.

19. Wickramasinghe VO, Venkitaraman AR. RNA Processing and Genome Stability: Cause and Consequence. Mol Cell. 2016; 61:496-505. https://doi.org/10.1016/j.molcel.2016.02.001. 
20. Rockx DA, Mason R, van Hoffen A, Barton MC, Citterio E, Bregman DB, van Zeeland AA, Vrieling H, Mullenders LH. UV-induced inhibition of transcription involves repression of transcription initiation and phosphorylation of RNA polymerase II. Proc Natl Acad Sci U S A. 2000; 97:105038. https://doi.org/10.1073/pnas.180169797.

21. Proietti-De-Santis L, Drane P, Egly JM. Cockayne syndrome $\mathrm{B}$ protein regulates the transcriptional program after UV irradiation. EMBO J. 2006; 25:1915-23. https:// doi.org/10.1038/sj.emboj.7601071.

22. Riley T, Sontag E, Chen P, Levine A. Transcriptional control of human p53-regulated genes. Nat Rev Mol Cell Biol. 2008; 9:402-12. https://doi.org/10.1038/nrm2395.

23. Medema RH, Macurek L. Checkpoint control and cancer. Oncogene. 2012; 31:2601-13. https://doi.org/10.1038/ onc.2011.451.

24. Mone MJ, Volker M, Nikaido O, Mullenders LH, van Zeeland AA, Verschure PJ, Manders EM, van Driel R. Local UV-induced DNA damage in cell nuclei results in local transcription inhibition. EMBO Rep. 2001; 2:1013-7. https://doi.org/10.1093/embo-reports/kve224.

25. Pankotai T, Bonhomme C, Chen D, Soutoglou E. DNAPKcs-dependent arrest of RNA polymerase II transcription in the presence of DNA breaks. Nat Struct Mol Biol. 2012; 19:276-82. https://doi.org/10.1038/nsmb.2224.

26. Shanbhag NM, Rafalska-Metcalf IU, Balane-Bolivar C, Janicki SM, Greenberg RA. ATM-dependent chromatin changes silence transcription in cis to DNA double-strand breaks. Cell. 2010; 141:970-81. https://doi.org/10.1016/j. cell.2010.04.038.

27. Ui A, Nagaura Y, Yasui A. Transcriptional elongation factor ENL phosphorylated by ATM recruits polycomb and switches off transcription for DSB repair. Mol Cell. 2015; 58:468-82. https://doi.org/10.1016/j.molcel.2015.03.023.

28. Camphausen K, Purow B, Sproull M, Scott T, Ozawa T, Deen DF, Tofilon PJ. Orthotopic growth of human glioma cells quantitatively and qualitatively influences radiation-induced changes in gene expression. Cancer Res. 2005; 65:10389-93. https://doi.org/10.1158/0008-5472.CAN-05-1904.

29. Amundson SA, Bittner M, Chen Y, Trent J, Meltzer P, Fornace AJ Jr. Fluorescent cDNA microarray hybridization reveals complexity and heterogeneity of cellular genotoxic stress responses. Oncogene. 1999; 18:3666-72. https://doi. org/10.1038/sj.onc. 1202676.

30. Amundson SA, Do KT, Vinikoor LC, Lee RA, Koch-Paiz CA, Ahn J, Reimers M, Chen Y, Scudiero DA, Weinstein JN, Trent JM, Bittner ML, Meltzer PS, et al. Integrating global gene expression and radiation survival parameters across the 60 cell lines of the National Cancer Institute Anticancer Drug Screen. Cancer Res. 2008; 68:415-24. https://doi.org/10.1158/0008-5472.CAN-07-2120.

31. Dutertre M, Vagner S. DNA-Damage Response RNABinding Proteins (DDRBPs): Perspectives from a New Class of Proteins and Their RNA Targets. J Mol Biol. 2017; 429:3139-3145. https://doi.org/10.1016/j.jmb.2016.09.019.
32. Dutertre M, Lambert S, Carreira A, Amor-Gueret M, Vagner S. DNA damage: RNA-binding proteins protect from near and far. Trends Biochem Sci. 2014; 39:141-9. https://doi. org/10.1016/j.tibs.2014.01.003.

33. Giono LE, Nieto Moreno N, Cambindo Botto AE, Dujardin G, Munoz MJ, Kornblihtt AR. The RNA Response to DNA Damage. J Mol Biol. 2016; 428:2636-51. https://doi. org/10.1016/j.jmb.2016.03.004.

34. Mellon I, Spivak G, Hanawalt PC. Selective removal of transcription-blocking DNA damage from the transcribed strand of the mammalian DHFR gene. Cell. 1987; 51:241-9.

35. Hanawalt PC, Spivak G. Transcription-coupled DNA repair: two decades of progress and surprises. Nat Rev Mol Cell Biol. 2008; 9:958-70. https://doi.org/10.1038/nrm2549.

36. Ju BG, Lunyak VV, Perissi V, Garcia-Bassets I, Rose DW, Glass CK, Rosenfeld MG. A topoisomerase IIbetamediated dsDNA break required for regulated transcription. Science. 2006; 312:1798-802. https://doi.org/10.1126/ science. 1127196.

37. Guha M, Saare M, Maslovskaja J, Kisand K, Liiv I, Haljasorg U, Tasa T, Metspalu A, Milani L, Peterson P. DNA breaks and chromatin structural changes enhance the transcription of autoimmune regulator target genes. J Biol Chem. 2017; 292:6542-54. https://doi.org/10.1074/jbc. M116.764704.

38. Wei F, Ojo D, Lin X, Wong N, He L, Yan J, Xu S, Major P, Tang D. BMI1 attenuates etoposide-induced G2/M checkpoints via reducing ATM activation. Oncogene. 2015; 34:3063-75. https://doi.org/10.1038/onc.2014.235.

39. Wei F, Xie Y, Tao L, Tang D. Both ERK1 and ERK2 kinases promote G2/M arrest in etoposide-treated MCF7 cells by facilitating ATM activation. Cell Signal. 2010; 22:1783-9. https://doi.org/10.1016/j.cellsig.2010.07.007.

40. Wei F, Yan J, Tang D, Lin X, He L, Xie Y, Tao L, Wang S. Inhibition of ERK activation enhances the repair of doublestranded breaks via non-homologous end joining by increasing DNA-PKcs activation. Biochim Biophys Acta. 2013; 1833:90100. https://doi.org/10.1016/j.bbamcr.2012.10.016.

41. Saarikangas J, Barral Y. Protein aggregation as a mechanism of adaptive cellular responses. Curr Genet. 2016; 62:71124. https://doi.org/10.1007/s00294-016-0596-0.

42. Olivieri F, Albertini MC, Orciani M, Ceka A, Cricca M, Procopio AD, Bonafe M. DNA damage response (DDR) and senescence: shuttled inflamma-miRNAs on the stage of inflamm-aging. Oncotarget. 2015; 6:35509-21. https:// doi.org/10.18632/oncotarget.5899.

43. Palmai-Pallag T, Bachrati CZ. Inflammation-induced DNA damage and damage-induced inflammation: a vicious cycle. Microbes Infect. 2014; 16:822-32. https://doi.org/10.1016/j. micinf.2014.10.001.

44. Gordon BS, Steiner JL, Williamson DL, Lang CH, Kimball SR. Emerging role for regulated in development and DNA damage 1 (REDD1) in the regulation of skeletal muscle metabolism. Am J Physiol Endocrinol Metab. 2016; 311:E157-74. https://doi.org/10.1152/ajpendo.00059.2016. 
45. Kono K, Ikui AE. A new cell cycle checkpoint that senses plasma membrane/cell wall damage in budding yeast. Bioessays. 2017; 39. https://doi.org/10.1002/ bies.201600210.

46. Sechi S, Frappaolo A, Belloni G, Colotti G, Giansanti MG. The multiple cellular functions of the oncoprotein Golgi phosphoprotein 3. Oncotarget. 2015; 6:3493-506. https:// doi.org/10.18632/oncotarget.3051.

47. Sandhir R, Halder A, Sunkaria A. Mitochondria as a centrally positioned hub in the innate immune response. Biochim Biophys Acta. 2017; 1863:1090-1097. https://doi. org/10.1016/j.bbadis.2016.10.020.

48. Marcomini I, Gasser SM. Nuclear organization in DNA end processing: Telomeres vs double-strand breaks. DNA Repair (Amst). 2015; 32:134-40. https://doi.org/10.1016/j. dnarep.2015.04.024.

49. Mullee LI, Morrison CG. Centrosomes in the DNA damage response--the hub outside the centre. Chromosome Res. 2016; 24:35-51. https://doi.org/10.1007/s10577-015-9503-7.

50. Awasthi P, Foiani M, Kumar A. ATM and ATR signaling at a glance. J Cell Sci. 2015; 128:4255-62. https://doi. org/10.1242/jcs. 169730.

51. Cimprich KA, Cortez D. ATR: an essential regulator of genome integrity. Nat Rev Mol Cell Biol. 2008; 9:616-27. https://doi.org/10.1038/nrm2450.

52. Pellegrino S, Altmeyer M. Interplay between Ubiquitin, SUMO, and Poly(ADP-Ribose) in the Cellular Response to Genotoxic Stress. Front Genet. 2016; 7:63. https://doi. org/10.3389/fgene.2016.00063.

53. Dantuma NP, van Attikum H. Spatiotemporal regulation of posttranslational modifications in the DNA damage response. EMBO J. 2016; 35:6-23. https://doi. org/10.15252/embj.201592595.

54. Tang D, Wu D, Hirao A, Lahti JM, Liu L, Mazza B, Kidd VJ, Mak TW, Ingram AJ. ERK activation mediates cell cycle arrest and apoptosis after DNA damage independently of p53. J Biol Chem. 2002; 277:12710-7. https://doi. org/10.1074/jbc.M111598200.

55. Amundson SA, Lee RA, Koch-Paiz CA, Bittner ML, Meltzer P, Trent JM, Fornace AJ Jr. Differential responses of stress genes to low dose-rate gamma irradiation. Mol Cancer Res. 2003; 1:445-52.

56. Luo W, Friedman MS, Shedden K, Hankenson KD, Woolf PJ. GAGE: generally applicable gene set enrichment for pathway analysis. BMC Bioinformatics. 2009; 10:161. https://doi.org/10.1186/1471-2105-10-161.

57. Yu G, He QY. ReactomePA: an R/Bioconductor package for reactome pathway analysis and visualization. Mol Biosyst. 2016; 12:477-9. https://doi.org/10.1039/c5mb00663e.

58. Boucas J, Fritz C, Schmitt A, Riabinska A, Thelen L, Peifer M, Leeser U, Nuernberg P, Altmueller J, Gaestel M, Dieterich C, Reinhardt HC. Label-Free ProteinRNA Interactome Analysis Identifies Khsrp Signaling Downstream of the p38/Mk2 Kinase Complex as a
Critical Modulator of Cell Cycle Progression. PLoS One. 2015; 10:e125745. https://doi.org/10.1371/journal. pone. 0125745 .

59. Li YY, Fu S, Wang XP, Wang HY, Zeng MS, Shao JY. Downregulation of c9orf86 in human breast cancer cells inhibits cell proliferation, invasion and tumor growth and correlates with survival of breast cancer patients. PLoS One. 2013; 8:e71764. https://doi.org/10.1371/journal.pone.0071764.

60. Tang H, Ji F, Sun J, Xie Y, Xu Y, Yue H. RBEL1 is required for osteosarcoma cell proliferation via inhibiting retinoblastoma 1. Mol Med Rep. 2016; 13:1275-80. https:// doi.org/10.3892/mmr.2015.4670.

61. Hagen J, Muniz VP, Falls KC, Reed SM, Taghiyev AF, Quelle FW, Gourronc FA, Klingelhutz AJ, Major HJ, Askeland RW, Sherman SK, O’Dorisio TM, Bellizzi AM, et al. RABL6A promotes G1-S phase progression and pancreatic neuroendocrine tumor cell proliferation in an Rb1-dependent manner. Cancer Res. 2014; 74:6661-70. https://doi.org/10.1158/0008-5472.CAN-13-3742.

62. Yan MD, Hong CC, Lai GM, Cheng AL, Lin YW, Chuang SE. Identification and characterization of a novel gene Saf transcribed from the opposite strand of Fas. Hum Mol Genet. 2005; 14:1465-74. https://doi.org/10.1093/hmg/ddi156.

63. Villamizar O, Chambers CB, Mo YY, Torry DS, Hofstrand R, Riberdy JM, Persons DA, Wilber A. Fas-antisense long noncoding RNA is differentially expressed during maturation of human erythrocytes and confers resistance to Fas-mediated cell death. Blood Cells Mol Dis. 2016; 58:57-66. https://doi.org/10.1016/j.bcmd.2016.03.002.

64. Sehgal L, Mathur R, Braun FK, Wise JF, Berkova Z, Neelapu S, Kwak LW, Samaniego F. FAS-antisense 1 IncRNA and production of soluble versus membrane Fas in B-cell lymphoma. Leukemia. 2014; 28:2376-87. https://doi. org/10.1038/leu.2014.126.

65. Kabacik S, Manning G, Raffy C, Bouffler S, Badie C. Time, dose and ataxia telangiectasia mutated (ATM) status dependency of coding and noncoding RNA expression after ionizing radiation exposure. Radiat Res. 2015; 183:325-37. https://doi.org/10.1667/RR13876.1.

66. Friedel CC, Dolken L. Metabolic tagging and purification of nascent RNA: implications for transcriptomics. Mol Biosyst. 2009; 5:1271-8. https://doi.org/10.1039/b911233b.

67. Munchel SE, Shultzaberger RK, Takizawa N, Weis K. Dynamic profiling of mRNA turnover reveals gene-specific and system-wide regulation of mRNA decay. Mol Biol Cell. 2011; 22:2787-95. https://doi.org/10.1091/mbc.E11-01-0028.

68. Dolken L, Ruzsics Z, Radle B, Friedel CC, Zimmer R, Mages J, Hoffmann R, Dickinson P, Forster T, Ghazal P, Koszinowski UH. High-resolution gene expression profiling for simultaneous kinetic parameter analysis of RNA synthesis and decay. RNA. 2008; 14:1959-72. https:// doi.org/10.1261/rna.1136108.

69. Rabani M, Levin JZ, Fan L, Adiconis X, Raychowdhury R, Garber M, Gnirke A, Nusbaum C, Hacohen N, Friedman N, Amit I, Regev A. Metabolic labeling of RNA uncovers 
principles of RNA production and degradation dynamics in mammalian cells. Nat Biotechnol. 2011; 29:436-42. https:// doi.org/10.1038/nbt.1861.

70. Fong YW, Cattoglio C, Tjian R. The intertwined roles of transcription and repair proteins. Mol Cell. 2013; 52:291302. https://doi.org/10.1016/j.molcel.2013.10.018.

71. Lin X, Ojo D, Wei F, Wong N, Gu Y, Tang D. A Novel Aspect of Tumorigenesis-BMI1 Functions in Regulating DNA Damage Response. Biomolecules. 2015; 5:3396-415. https://doi.org/10.3390/biom5043396.

72. Khodarev NN, Park JO, Yu J, Gupta N, Nodzenski E, Roizman B, Weichselbaum RR. Dose-dependent and independent temporal patterns of gene responses to ionizing radiation in normal and tumor cells and tumor xenografts. Proc Natl Acad Sci U S A. 2001; 98:12665-70. https://doi. org/10.1073/pnas.211443698.

73. Tidball AM, Neely MD, Chamberlin R, Aboud AA, Kumar KK, Han B, Bryan MR, Aschner M, Ess KC, Bowman AB. Genomic Instability Associated with p53 Knockdown in the Generation of Huntington's Disease Human Induced Pluripotent Stem Cells. PLoS One. 2016; 11:e0150372. https://doi.org/10.1371/journal.pone.0150372.

74. Kamisugi Y, Whitaker JW, Cuming AC. The Transcriptional Response to DNA-Double-Strand Breaks in Physcomitrella patens. PLoS One. 2016; 11:e0161204. https://doi. org/10.1371/journal.pone.0161204.

75. Leung AW, Hung SS, Backstrom I, Ricaurte D, Kwok B, Poon S, McKinney S, Segovia R, Rawji J, Qadir MA, Aparicio S, Stirling PC, Steidl C, et al. Combined Use of Gene Expression Modeling and siRNA Screening Identifies Genes and Pathways Which Enhance the Activity of Cisplatin When Added at No Effect Levels to Non-Small Cell Lung Cancer Cells In Vitro. PLoS One. 2016; 11:e0150675. https:// doi.org/10.1371/journal.pone.0150675.

76. Smith CC, Aylott MC, Fisher KJ, Lynch AM, Gooderham NJ. DNA damage responses after exposure to DNAbased products. J Gene Med. 2006; 8:175-85. https://doi. org/10.1002/jgm.827.

77. Amundson SA, Patterson A, Do KT, Fornace AJ Jr. A nucleotide excision repair master-switch: p53 regulated coordinate induction of global genomic repair genes. Cancer Biol Ther. 2002; 1:145-9.

78. Derrien T, Johnson R, Bussotti G, Tanzer A, Djebali S, Tilgner H, Guernec G, Martin D, Merkel A, Knowles DG, Lagarde J, Veeravalli L, Ruan X, et al. The GENCODE v7 catalog of human long noncoding RNAs: analysis of their gene structure, evolution, and expression. Genome Res. 2012; 22:1775-89. https://doi.org/10.1101/gr.132159.111.

79. Zhang Y, He Q, Hu Z, Feng Y, Fan L, Tang Z, Yuan J, Shan W, Li C, Hu X, Tanyi JL, Fan Y, Huang Q, et al. Long noncoding RNA LINP1 regulates repair of DNA doublestrand breaks in triple-negative breast cancer. Nat Struct Mol Biol. 2016; 23:522-30. https://doi.org/10.1038/nsmb.3211.

80. Hung T, Wang Y, Lin MF, Koegel AK, Kotake Y, Grant GD, Horlings HM, Shah N, Umbricht C, Wang P, Wang
Y, Kong B, Langerod A, et al. Extensive and coordinated transcription of noncoding RNAs within cell-cycle promoters. Nat Genet. 2011; 43:621-9. https://doi. org/10.1038/ng.848.

81. Nanya M, Sato M, Tanimoto K, Tozuka M, Mizutani S, Takagi M. Dysregulation of the DNA Damage Response and KMT2A Rearrangement in Fetal Liver Hematopoietic Cells. PLoS One. 2015; 10:e144540. https://doi. org/10.1371/journal.pone.0144540.

82. Wu D, Chen B, Parihar K, He L, Fan C, Zhang J, Liu L, Gillis A, Bruce A, Kapoor A, Tang D. ERK activity facilitates activation of the S-phase DNA damage checkpoint by modulating ATR function. Oncogene. 2006; 25:1153-64. https://doi.org/10.1038/sj.onc.1209148.

83. Wei F, Xie Y, He L, Tao L, Tang D. ERK1 and ERK2 kinases activate hydroxyurea-induced S-phase checkpoint in MCF7 cells by mediating ATR activation. Cell Signal. 2011; 23:259-68. https://doi.org/10.1016/j.cellsig.2010.09.010.

84. He L, Fan C, Kapoor A, Ingram AJ, Rybak AP, Austin RC, Dickhout J, Cutz JC, Scholey J, Tang D. alpha-Mannosidase $2 \mathrm{C} 1$ attenuates PTEN function in prostate cancer cells. Nat Commun. 2011; 2:307. https://doi.org/10.1038/ ncomms 1309 .

85. He L, Ingram A, Rybak AP, Tang D. Shank-interacting protein-like 1 promotes tumorigenesis via PTEN inhibition in human tumor cells. J Clin Invest. 2010; 120:2094-108. https://doi.org/10.1172/JCI40778.

86. Yan J, De Melo J, Cutz JC, Aziz T, Tang D. Aldehyde dehydrogenase 3A1 associates with prostate tumorigenesis. Br J Cancer. 2014; 110:2593-603. https://doi.org/10.1038/ bjc.2014.201.

87. Yan J, Ojo D, Kapoor A, Lin X, Pinthus JH, Aziz T, Bismar TA, Wei F, Wong N, De Melo J, Cutz JC, Major P, Wood G, et al. Neural Cell Adhesion Protein CNTN1 Promotes the Metastatic Progression of Prostate Cancer. Cancer Res. 2016; 76:1603-14. https://doi.org/10.1158/0008-5472. CAN-15-1898.

88. Kim D, Langmead B, Salzberg SL. HISAT: a fast spliced aligner with low memory requirements. Nat Methods. 2015; 12:357-60. https://doi.org/10.1038/nmeth.3317.

89. Langmead B, Trapnell C, Pop M, Salzberg SL. Ultrafast and memory-efficient alignment of short DNA sequences to the human genome. Genome Biol. 2009; 10:R25. https://doi. org/10.1186/gb-2009-10-3-r25.

90. Li B, Dewey CN. RSEM: accurate transcript quantification from RNA-Seq data with or without a reference genome. BMC Bioinformatics. 2011; 12:323. https://doi. org/10.1186/1471-2105-12-323.

91. Benjamini Y, Drai D, Elmer G, Kafkafi N, Golani I. Controlling the false discovery rate in behavior genetics research. Behav Brain Res. 2001; 125:279-84. 